\title{
Stromatolites from the Aptian Crato Formation, a hypersaline lake system in the Araripe Basin, northeastern Brazil
}

\author{
Lucas Veríssimo Warren ${ }^{1}$ Filipe Giovanini Varejão ${ }^{1}$. Fernanda Quaglio ${ }^{1}$. \\ Marcello Guimarães Simões ${ }^{2} \cdot$ Franz Theodor Fürsich $^{3}$ - Daniel Gustavo Poiré ${ }^{\text {. }}$ \\ Bruno Catto $^{5}$ Mario Luis Assine ${ }^{1}$
}

Received: 21 June 2016 / Accepted: 11 November 2016 / Published online: 19 November 2016

(C) Springer-Verlag Berlin Heidelberg 2016

\begin{abstract}
The origin of the Cretaceous laminites of the Crato Formation, Araripe Basin, northeastern Brazil, has been intensely debated since the beginning of the last century. The monotonous, up to 10 -m-thick succession composed of very fine fossiliferous laminites in the middle of the unit lacked diagnostic features for assigning a chemically or biologically induced origin for this facies. The presence of a highly diverse and very well preserved allochthonous to parautochthonous fossil assemblage, associated with scattered halite pseudomorphs throughout the succession, led many authors to believe that these limestones were chemically deposited in a highly stressful, evaporitic shallow-water environment, such as a hypersaline lake close to marine environments. Recently, a micro- and ultrastructural analysis of the laminites yielded structures undoubtedly associated with a biological origin. Several examples of lithified in situ preserved coccoid and filamentous cells and extracellular polymeric substances suggest that the deposition of the laminated limestones was, at some levels,
\end{abstract}

Lucas Veríssimo Warren

warren@rc.unesp.br

1 Instituto de Geociências e Ciências Exatas, Universidade Estadual Paulista, Avenida 24A, 1515, Rio Claro 13506-900, Brazil

2 Departamento de Zoologia, Instituto de Biociências, Universidade Estadual Paulista, Distrito de Rubião Júnior, Botucatu 18618-000, Brazil

3 GeoZentrum Nordbayern, FG Paläoumwelt, FriedrichAlexander-Universität Erlangen-Nürnberg, Loewenichstr 28, 91054 Erlangen, Germany

4 Centro de Investigaciones Geológicas (UNLP-Conicet), Diagonal 113 n$^{\circ}$ 275, esq. 64, 1900 La Plata, Argentina

5 Petróleo Brasileiro-Matriz, Centro, Avenida República do Chile, 65, Rio de Janeiro 20031-912, Brazil strongly influenced by microbial activity. Here, we record various examples of stromatolite microbialites (mounds, domes, and pseudo-columns) found at distinct stratigraphic levels in the middle part of the Crato Formation. Macro-, meso-, and microscopic features confirm the biologically induced mineralization and the existence of metabolic activity of microbes during the formation of the laminites. Biomat growth may also have played a major role in the excellent preservation of fossils in this famous Cretaceous Konservat-Lagerstätte from Brazil.

Keywords Microbialites $\cdot$ Biologically induced carbonates · Santana Group · Lower Cretaceous · Aptian · Araripe Basin

\section{Introduction}

Laminated limestones are an intriguing sedimentary facies that occur in the geologic record from the Archean to the Holocene (e.g., Barthel et al. 1994; Sumner 1997; Trichet et al. 2001; Schopf 2006; Wittkop et al. 2009). Modern carbonate stromatolites occur in very different environments, from shallow-marine coastal settings (Dravis 1983; Reid et al. 1995) to high-altitude Andean lakes (Poiré et al. 2010; Farías et al. 2011, 2013). Simple, parallel, thin lamination in carbonate rocks can be formed by both organic and inorganic processes and does not allow to determine the origin of the deposit with certainty (Demicco and Hardie 1994). Furthermore, the usual absence of macroscopic and mesoscopic features, such as wrinkle surfaces and convex forms, make it difficult to define the chemical or biogenic origin of the carbonate (Buick et al. 1981; Riding 1991, 2008; Grotzinger and Knoll 1999). Due to these particularities, micro- and ultrastructural analyses are considered 


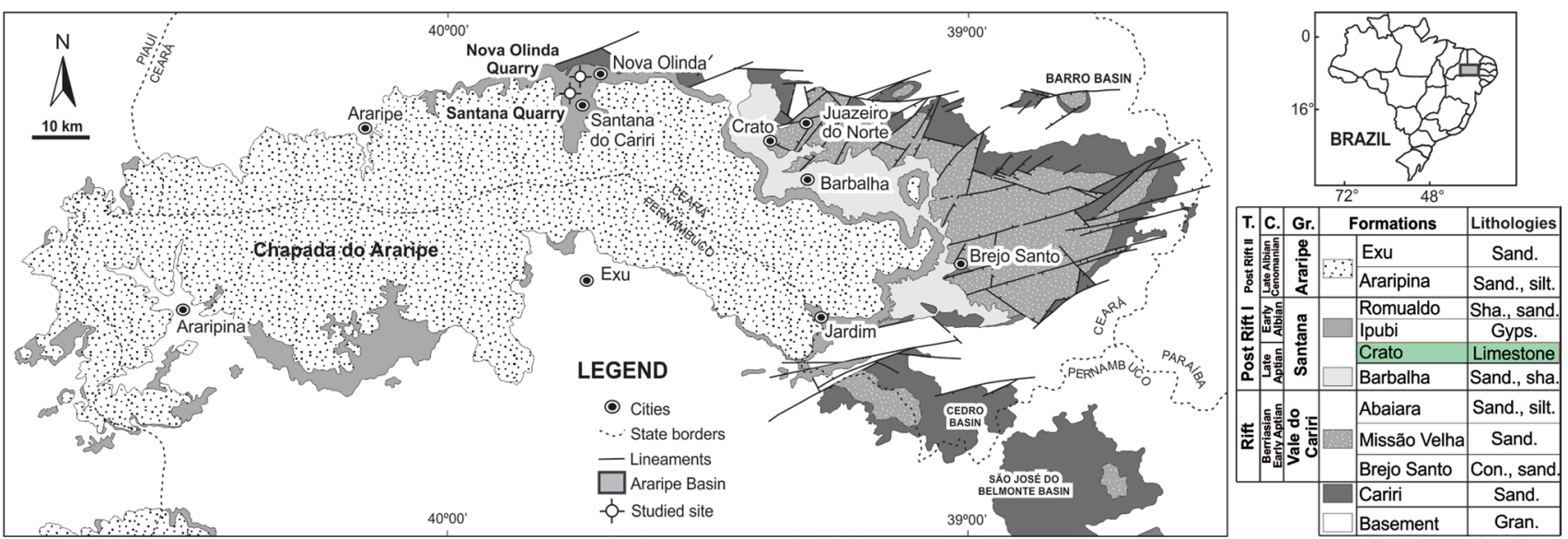

Fig. 1 Geologic map of the Chapada do Araripe area with the location of the studied sites (modified from Assine 2007). The stratigraphic column is summarized at the right. T tectono-stratigraphy; Gr group; Sand. sandstone; Silt. siltstone; Sha. shale; Gyps gypsum; Con. conglomerate

a powerful tool to investigate evidence of biomineralization, organomineralization, or chemical mineralization in carbonates (Benzerara et al. 2006; Dupraz et al. 2009). The presence of preserved cells (filaments, coccoids), EPS (extracellular polymeric substances) framework, microto nanometer organominerals and organic biomarkers are important evidence to identify the organic-derived origin of carbonates (Défarge et al. 1996; Jahnke et al. 2001; Dupraz et al. 2009).

The laminated facies of the Crato Formation, Aptian, Araripe Basin, northeastern Brazil, was object of several studies (Neumann 1999; Martill et al. 2007a; Heimhofer et al. 2010) mainly due to the presence of its spectacular paleontological archive. Fossil specimens are exceptionally well preserved, including important morphological details and soft tissues (Sayão and Kellner 1998), and define the Crato Formation as a Konservat-Lagerstätte. The unusual fossil preservation suggests that the carbonates were deposited in a reducing, hypersaline environment probably under the influence of microbial mats or even authigenic precipitation of calcite (Martill et al. 2007b; Heimhofer et al. 2010; Barling et al. 2015). Recent studies provide new data about the microbial origin of some laminated carbonate beds of the Crato Formation, developed in a saline environment, as indicated by halite hoppers and successive gypsum layers (Catto et al. 2016).

Here, several examples of EPS framework, calcified coccoid and filamentous cells, and organominerals are recorded in the laminites of the analyzed stratigraphic interval, revealing the microbial influence during precipitation of such carbonate facies (Catto et al. 2016). In addition, we record and describe, for the first time, various examples of stromatolite structures found in carbonates of the lower Crato Formation (Nova Olinda Member) cropping out in quarries located in the vicinity of Santana do
Cariri and Nova Olinda towns, State of Ceará, northeastern Brazil (Figs. 1, 2). The stromatolite structures occur at several stratigraphic levels, which apparently formed under shallow-water conditions, given their association with halite hoppers, oncoids, wrinkle structures, and breccias. They constitute bioherms varying in size from 5 to $80 \mathrm{~cm}$ with domal and pseudo-columnar shapes, laterally separated by laminites. This confirms the intrinsic relationship between the limestones of the lower Crato Formation and biological activity related to biomineralization of calcium carbonate. It also strengthens the intrinsic relationship between microbialites and stressful environments, as well as the connection between microbial mats and the exceptional preservation of the fossils in this unit.

\section{Geologic setting}

The Gondwana breakup triggered the development of several rift basins in Brazil during the Cretaceous. Evidence of this noteworthy event extends from the Brazilian Continental Margin to intracratonic regions (Magnavita and Cupertino 1987; Milani and Davison 1988). The mechanical subsidence tied to the break-up of Africa and South America led to the formation of several hinterland basins at the intersection between the transtensive and distensive branches of the rift system (Matos 1992). The Araripe Basin is one of the most prominent examples of this phase because of its large extension and complex geological evolution (Assine 2007).

The Araripe Basin is limited in the north by the Patos Shear Zone and in the south by the Pernambuco Shear Zone, both oriented in an $\mathrm{E}-\mathrm{W}$ direction (Castro and Branco 1999; Brito Neves et al. 2000). Besides these ductile shear zones, the structural framework also comprises 
Fig. 2 Stratigraphy of the study area. a Stratigraphic framework scheme of the Araripe Basin with the location of the studied sections/outcrops. The distance between the two main quarry areas is approximately $20 \mathrm{~km}$. $D S$ - 1 depositional sequence 1; $D S$-2 depositional sequence 2; $D S$-3 depositional sequence 3 (Assine et al. 2014). This scheme has no vertical scale. b Composite stratigraphic section of laminites of the lower Crato Formation in the Santana quarries with positions of the domal and pseudo-columnar microbialite levels. c Composite stratigraphic section of laminites in the Nova Olinda quarries showing the positions of the stromatolite levels. The bands in light gray correlate with the microbialite levels in the two localities. $M$ mudstone (carbonate/siliciclastic); $W$ wackestone; $G$ grainstone; $B$ boundstone

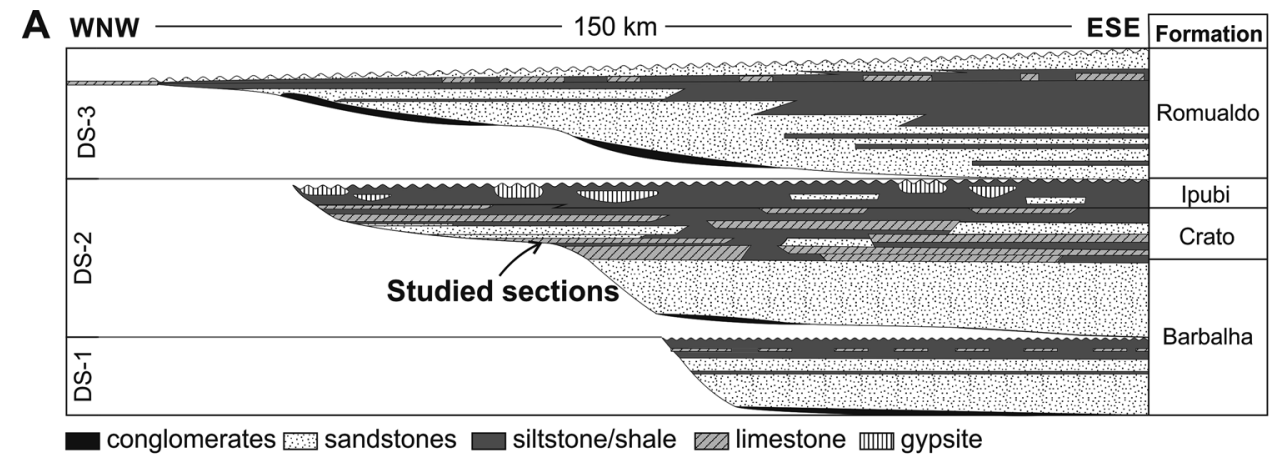

B Santana Section

C Nova Olinda Section

$8.9 \mathrm{~m}$

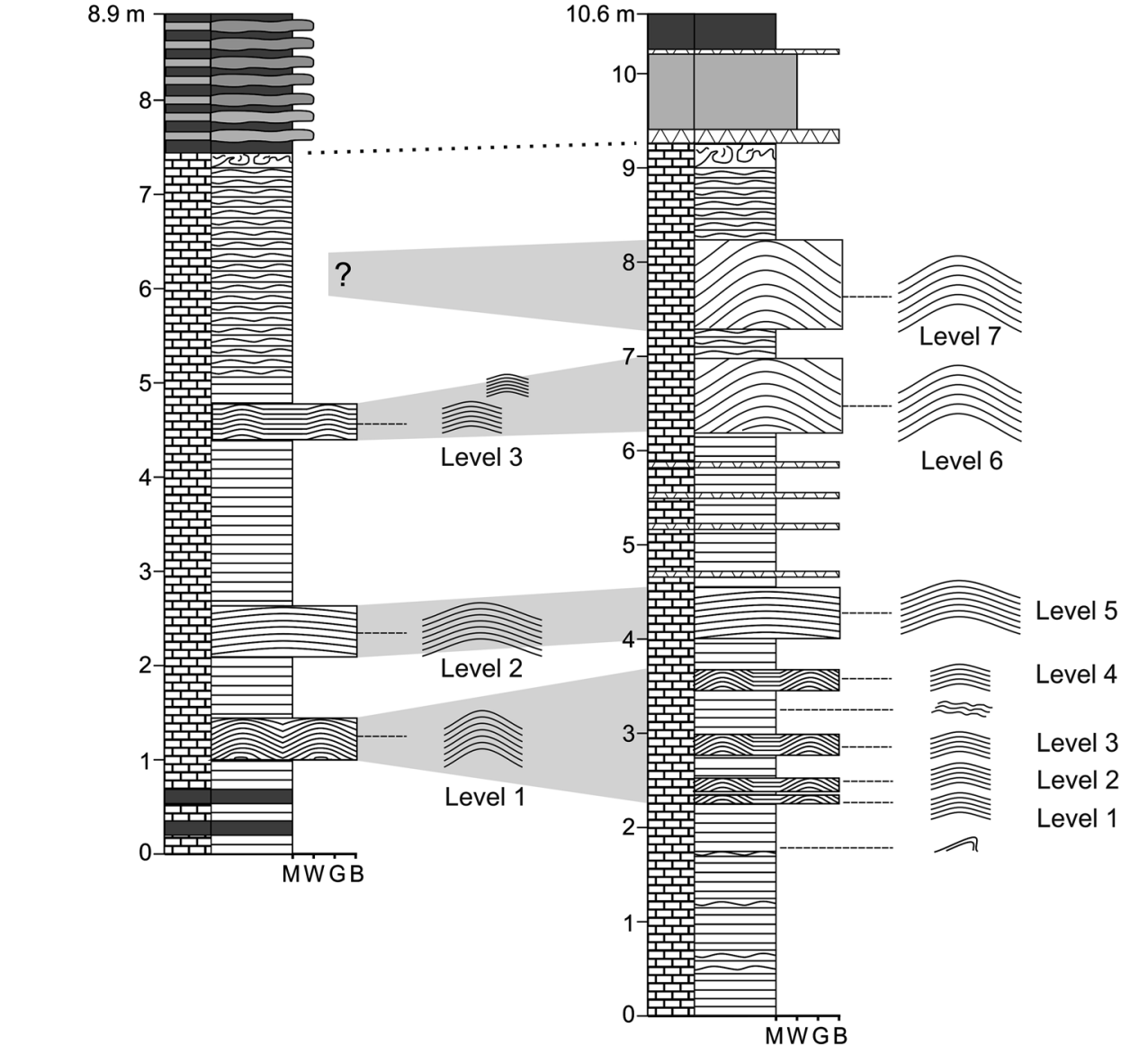

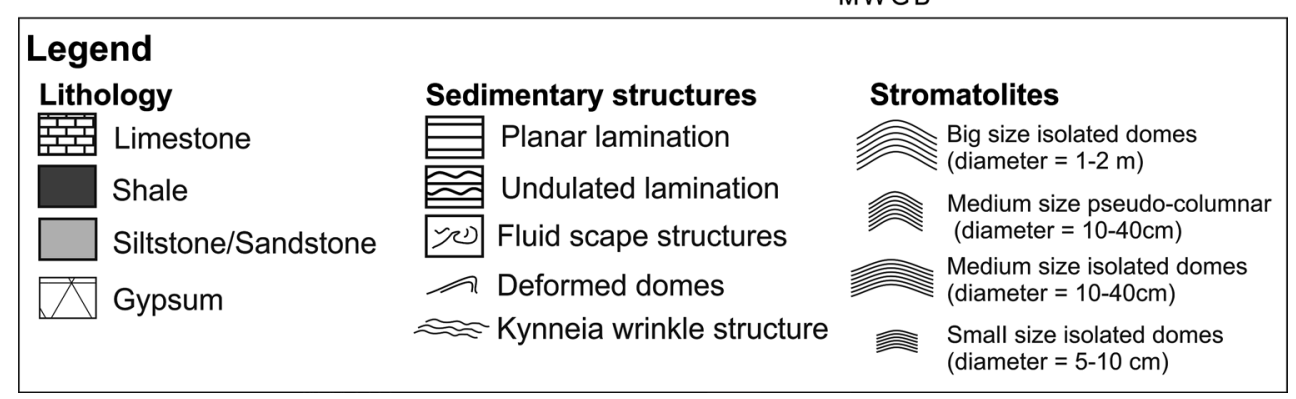

NE-SW, NW-SE, and E-W normal and reverse faults (Matos 1992; Marques et al. 2014). The reactivation of NE-SW lineaments was responsible for the development of a horst-graben system in the basin that gave origin to the Feira Nova and Cariri sub-basins, separated by the Dom Leme High (Ponte and Ponte Filho 1996). 
Table 1 Information on the five quarries in which stromatolitic structures have been documented

\begin{tabular}{llllll}
\hline Quarry & County & District & Local name & Coordinates & Present state \\
\hline Nova Olinda 1 & Nova Olinda & - & Três Irmãos & $7^{\circ} 06^{\prime} 53.38^{\prime \prime} \mathrm{S}$ & Active quarry \\
& & & & $39^{\circ} 41^{\prime} 48.96^{\prime \prime} \mathrm{W}$ & \\
Nova Olinda 2 & \multirow{2}{*}{ Nova Olinda } & - & - & $7^{\circ} 07^{\prime} 23.65^{\prime \prime} \mathrm{S}$ & Active quarry \\
& & & & $39^{\circ} 41^{\prime} 53.20^{\prime \prime} \mathrm{W}$ & \\
Nova Olinda 3 & \multirow{2}{*}{ Nova Olinda } & - & - & $7^{\circ} 06^{\prime} 37.36^{\prime \prime} \mathrm{S}$ & Abandoned quarry \\
& & & $39^{\circ} 42^{\prime} 23.34^{\prime \prime} \mathrm{W}$ & \\
Santana 1 & \multirow{2}{*}{ Santana do Cariri } & Inhumas & - & $7^{\circ} 10^{\prime} 40.49^{\prime \prime} \mathrm{S}$ & Partially abandoned quarry \\
& & & $39^{\circ} 45^{\prime} 27.71^{\prime \prime} \mathrm{W}$ & \\
Santana 2 & \multirow{2}{*}{ Santana do Cariri } & Inhumas & - & $7^{\circ} 10^{\prime} 41.82^{\prime \prime} \mathrm{S}$ & Partially abandoned quarry \\
& & & & $39^{\circ} 45^{\prime} 23.52^{\prime \prime} \mathrm{W}$ & \\
\hline
\end{tabular}

Sedimentation started in the Paleozoic and continued during Mesozoic (Jurassic and Cretaceous) times. The rift basin is organized in three major tectono-stratigraphic phases, the pre-rift, syn-rift, and post-rift megasequences (Assine et al. 2014). The pre-rift is characterized by continental siliciclastic units deposited during the Jurassic, while the syn-rift phase, developed in the Berriasian-Early Aptian, was formed in lacustrine and alluvial settings (Assine 2007). The post-rift megasequence is divided into two tectonic events: (1) post-rift I (Late Aptian-Early Albian), characterized by mixed siliciclastic-carbonate-evaporite successions; and (2) post-rift II (Albian-Cenomanian), with fluvial deposits (Assine et al. 2014). The post-rift I megasequence (Santana Group) is represented from base to top by the Barbalha, Crato, Ipubi, and Romualdo Formations, organized in three depositional sequences, encompassing the late Aptian to earliest Albian stages (Fig. 2a; Assine et al. 2014). The second depositional sequence is formed at base by a transgressive stacking of fluvial and lacustrine deposits of the Barbalha Formation followed by the highstand Crato Formation and culminates in the evaporites of the Ipubi Formation (Assine et al. 2014). The Crato Formation is recognized worldwide as a KonservatLagerstätte, due to its well-preserved fossil content (Martill et al. 2007a). The main fossils are arthropods (i.e., insects, ostracods, crustaceans, and arachnids), small fishes, chelonids, and pterosaurs. The quality of preservation of the flora, including algae and gymnosperms as well as angiosperms in their first diversification phase, is also spectacular (Martill et al. 2007a; Heimhofer and Hochuli 2010).

The Crato Formation comprises a 60-m-thick succession and is composed of metric-scale laminated carbonate units interlayered with equally thick successions of green shales and fine-to-coarse sandstones (Silva and Neumann 2003). The sections exposed in the Nova Olinda and Santana quarries (Fig. 2; Table 1), near Nova Olinda, Ceará, are the most complete ones in this part of the Araripe Basin. The quarries contain a tabular unit of laminites, approximately 10 $\mathrm{m}$ thick (Fig. 3a, b), characterized by a monotonous succession of horizontal, sub-millimetric thick layers of pale to dark carbonate mudstones. The presence of scattered halite pseudomorphs (halite hoppers, Fig. 3c) in distinct carbonate levels suggests that the Crato Formation has been deposited under fluctuating salinity conditions (Martill et al. 2007b; Heimhofer et al. 2010). Despite evidence of microbial activity for the origin of the Crato limestones (Neumann 1999; Catto et al. 2016) diagnostic features, such as domal microbial structures, have never been formally described for the main carbonate bed of this unit.

The rich fossil assemblage of the Crato Formation was originally interpreted as having lived in a non-marine setting (Mabesoone and Tinoco 1973), probably in a saline lacustrine environment close to marine environments (Assine 1992, 2007; Neumann 1999). More recently, several authors (e.g., Mohr and Eklund 2003; Makarkin and Menon 2005; Martill et al. 2007b; Do Carmo et al. 2008; Baez et al. 2009) suggested that the carbonates were deposited in a hypersaline lagoon system with restricted connection to an epeiric sea in the southeast (Assine et al. 2016). Here we regard the earlier view as more likely because of the absence of marine fossils. Episodic freshwater discharges lowered the salinity in the lake and promoted water level fluctuations (Neumann et al. 2003). Anoxic/dysoxic conditions must have prevailed in deeper bottom waters (Martill et al. 2007b). Climate during this period was probably seasonally humid to dry (Makarkin and Menon 2005; Martins-Neto 2006). Despite evidence of a stressful environment, fishes (genus Dastilbe) and plant remains are quite common throughout the succession (Fig. 3d). The sedimentary succession is indicative of deposition in a prograding sequence (Assine et al. 2014). Deposition of laminated limestones directly above the basement points to the rapid expansion of the basin (Assine 2007).

\section{Materials and methods}

The study area is located at the northern limit of the Araripe Basin in the vicinities of the Santana do Cariri (Santana quarries) and Nova Olinda (Nova Olinda quarries) towns, 

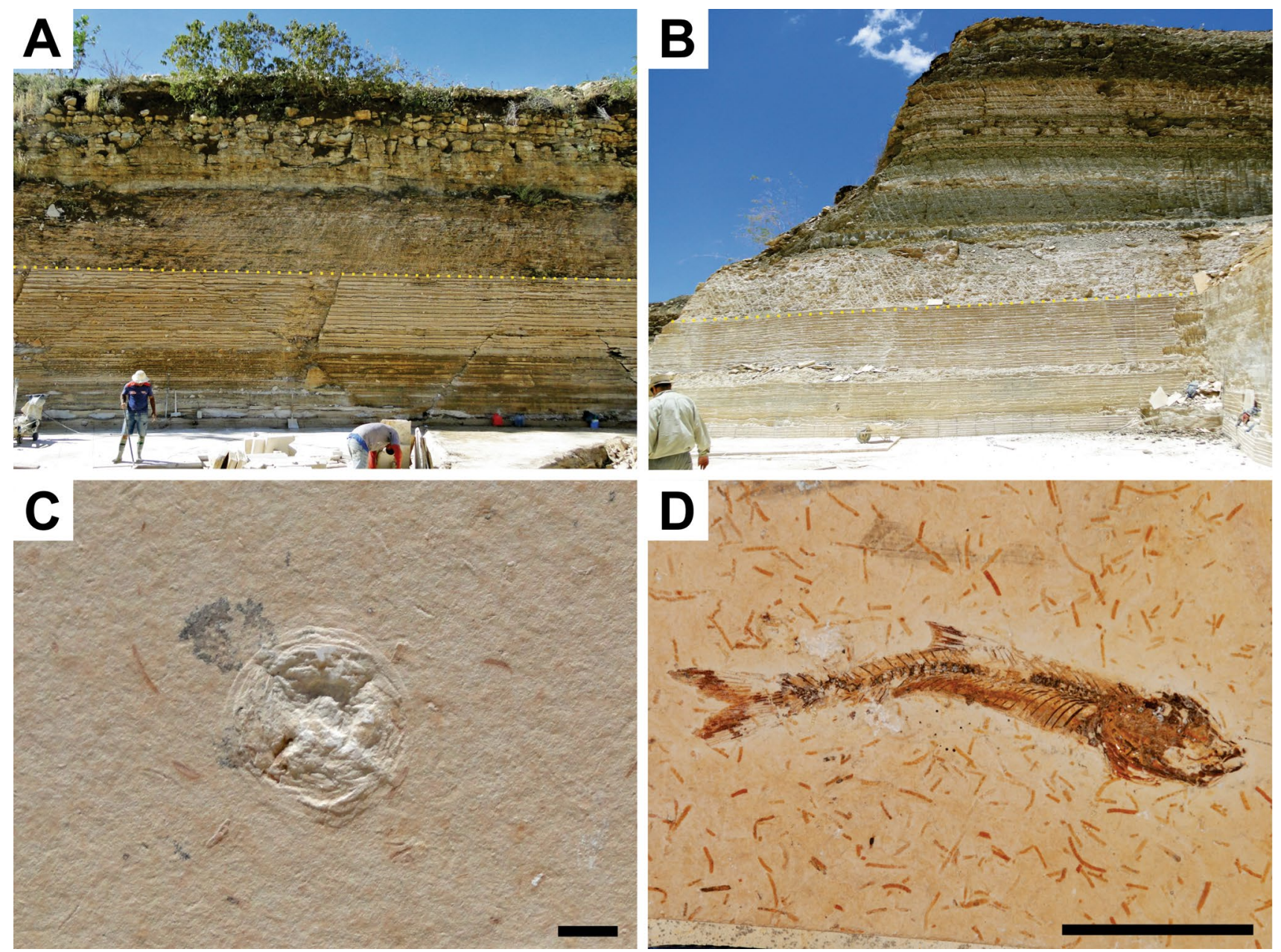

Fig. 3 Sedimentary facies of the Crato Formation in the Nova Olinda Quarry 1. a Sedimentary succession of the middle Crato Formation showing the basal laminated carbonates overlain by heterolithic siltstone and shale layers. $\mathbf{b}$ Thinly laminated carbonates at the base of

Nova Olinda Quarry 1 overlain by a mixed siliciclastic-carbonate succession. c Detail of centimeter-sized halite hopper crystal. d The small fish Dastilbe sp. is a common faunal element of the laminated carbonate facies. The scale bar in $\mathbf{c}$ and $\mathbf{d}$ is $1 \mathrm{~cm}$

State of Ceará, northeastern Brazil (Fig. 1). For detailed information on the position of quarries with the stromatolitic structures, see Table 1 . Most of the microbialitebearing outcrops occur in the lower Crato Formation. During the fieldwork, special attention was paid to the detailed measurement of the carbonate succession and description of domal microbialites, including characterization of their composition, associated sedimentary structures, bed thicknesses, contacts and geometry, as well as presence of fossils and salt pseudomorphs. The macroscopic morphometric measurements of the domes included diameter, longest and shortest axes, height, and margin thickness. We also observed the presence (or absence) of collapsed areas, vugs and fenestral cavities, coalescent forms, and other structures suspect of biological origin. We collected ten slabs from the Santana quarries for examination in the laboratory. In addition, 15 petrographic thin-sections of laminated carbonates and domal stromatolites were examined

under both normal and polarized light using a Zeiss Axio Imager A.2 binocular petrographic microscope and a Zeiss Stereo Discovery V.12 binocular magnifying glass, at the Center for Geosciences Applied to Petroleum Geology, São Paulo State University (UNESPetro-UNESP). The macrotextures and mineralogical composition of the microbialites were analyzed under a scanning electron microscope (SEM), whereas the micro- and ultrastructural images were acquired with the SEM X-ray energy-dispersive spectrometer (Model Zeiss Evo MA15, operated at EHT 20-30 kV and 40-80 Pa pressure), linked to the system Bruker EDS. The samples were covered with a thin layer of carbon in order to increase the conductivity.

For microbialite classification and description of macro-, meso-, and microstructural features, we used the very comprehensive protocol of Fairchild et al. (2015), complemented by data in Hofmann (1969), Preiss (1972), Walter (1972), and Grey (1989). Rock samples (slabs) and 
thin-sections are housed in the Laboratory of Sedimentology of the Institute of Geosciences and Exact Sciences, UNESP.

\section{Stromatolites of the Crato Formation}

In the Santana quarries, the stratigraphic section consists of 5-m-thick, very finely planar-laminated limestones interbedded with three levels of stromatolites (Fig. 2b), succeeded by $2.5 \mathrm{~m}$ of mudstone with undulated lamination. This succession is covered by about $1.5 \mathrm{~m}$ of shales interbedded with undulated beds of massive siltstones/very fine grained sandstones (Fig. 2b). In the Nova Olinda quarries, seven levels of stromatolites occur in an approximately 9-m-thick stratigraphic section (Fig. 2c). The correlation with the stromatolite levels from the Santana quarries are tentatively presented in the Fig. $2 \mathrm{~b}$ and c. Levels $1-4$ in the Nova Olinda quarries stratigraphically correspond to the Level 1 from the Santana quarries, but their morphologies are different (see Fig. 2b, c; Table 2). Level 2 from Santana quarries stratigraphically and morphologically corresponds to Level 5 from Nova Olinda quarries. Level 3 in the Santana succession was correlated with Level 6 in the Nova Olinda succession (Fig. 2b, c), but in the last quarry (i.e., Nova Olinda 3) the stromatolites are considerably larger (up to $100 \mathrm{~cm}$ high) and discontinuous with lateral size variation.

In the Santana Quarry 1, the stromatolites occur in the lower part of an at least 7.5-m-thick package located in the lower part of the Crato Formation (Fig. 2c). Microbialite levels have a wide lateral extension $(>100 \mathrm{~m})$ and a minimum and maximum thickness of $\sim 20$ to $60 \mathrm{~cm}$, respectively. These layers start with horizontal-laminated facies (Fig. 3a) and culminate in small-to-medium domes and low-relief mounds. Each stromatolite bed is formed by domes and pseudo-columns laterally separated by laminites. The contact between the domes/columns and laminites is transitional, marked by the gradual decreasing size of the bioherms until the laminae are again perfectly horizontal.

Microbialites occur as coalescent structures in the basal level (Level 1, Fig. 4) as comparatively steeply inclined structures from $30 \mathrm{~cm}$ to up to $46 \mathrm{~cm}$ in height, and with a maximum diameter of $170 \mathrm{~cm}$ at the base, and $60 \mathrm{~cm}$ at the top (Table 2; Fig. 4a, b). The gently inclined, distinctly pseudo-columnar structures are almost contiguous, with lenticular to equidimensional cross-sections (Fig. 4c). Each structure has a symmetric convexity and exhibits internal undulated laminae. Rarely, centimeter-sized elliptic oncoids occur in laminae between domes (Fig. 4d). Pseudo-columns of Level 1 show characteristic pale to dark grey colors, which represent the preserved organic matter of the EPS (Catto et al. 2016). Analysis of the micromorphology revealed a convex-upward and closely spaced lamination. Each lamina is approximately $0.25 \mathrm{~mm}$ thick with a microsparitic texture and occasionally secondarily silicified. Between laminae usually preserved dark organic matter and fenestral porosity occur (Fig. 5). Spherules, around $15 \mu \mathrm{m}$ in diameter and mainly composed of microcrystalline silica, occur in clusters and dispersed between laminae (Fig. 6).

The intermediate microbialite level of the Santana Quarry 1 (Level 2) occurs $\sim 1.5 \mathrm{~m}$ above Level 1 and consists of low discontinuous domes (Fig. $7 \mathrm{a}-\mathrm{c}$ ) of $25-\mathrm{cm}$ height and 50-cm length. Domes are separated $(5-25 \mathrm{~cm})$ by horizontal/crinkly laminites intervals (Fig. 7a). All structures have a low relief (Fig. 7c-e) and a faintly curved vertical growth vector towards the $\mathrm{S}$ and SE. Domes are slightly asymmetric and locally coalesce. Each structure has a low-to-moderate convexity profile with flat laminae (Fig. 7d) that occasionally grade laterally into horizontal laminites (Fig. 7a-c). Within the domes, vug porosity is quite common, while the most abundant porosity between the laminae is of the fenestral type.

The upper microbialite level (Level 3) occurs $2.2 \mathrm{~m}$ above Level 2 and characterizes a discontinuous layer with isolated, domal microbialites. In the quarry face, all analyzed specimens at this level are a few centimeters high (maximum: $5 \mathrm{~cm}$ ), with growing convexity profile from base to top, and are separated from each other by horizontal laminites. The domes are rounded, discontinuous, and show a straight, vertical growth vector. Each structure observed has a low convexity, composed of continuous, flat laminae that show high symmetry. In one corner of the quarry, this level was exposed as a 6-m-long and 2-m-wide bedding plane where at least nine small mounds, varying in size from $40 \times 30 \mathrm{~cm}$ to $100 \times 40 \mathrm{~cm}$ were encountered. The tallest mound is $5 \mathrm{~cm}$ high. In plan-view, the mounds are parallel to each other, and aligned in a NE-SW direction. Distances between mounds vary from $25 \mathrm{~cm}$ to nearly $1 \mathrm{~m}$.

In the southeastern face of the Nova Olinda quarries, five microbial levels occur within a 2-m-thick package of the laminated carbonate unit (Fig. 8a). Level 1 occurs at the base of the exposed quarry face (Nova Olinda 1) and is only poorly exposed (Figs. 2, 9a, b). Level 2 is separated from Level 1 only by $5-6 \mathrm{~cm}$ and includes 30-cm-long and 10-cm-high mounds. Most observations come from Level 3 that is $\sim 23 \mathrm{~cm}$ above Level 2 . The gently convex, more or less symmetric mounds vary between $3-7 \mathrm{~cm}$ in height and $14-30 \mathrm{~cm}$ in length. Above this interval, Kinneyiatype wrinkle structures associated with radial cracks, the first stage of formation of halite crystals, are quite common (Fig. 9c). As in the case of the Santana quarries, the fine lamination does not exhibit internal discontinuities or any other signs of truncation. Laminae thickness increases 
Table 2 Description of the macro-, meso-, and micromorphological features of the stromatolite-like microbialites from the Crato Formation

\begin{tabular}{|c|c|c|c|c|c|}
\hline \multicolumn{2}{|c|}{ Morphological features } & \multicolumn{4}{|c|}{ Quarries and microbialite levels } \\
\hline & & \multirow{2}{*}{$\begin{array}{l}\text { Santana } 1 \\
\text { Level } 1\end{array}$} & \multirow{2}{*}{$\begin{array}{l}\text { Santana } 1 / \text { Nova } \\
\text { Olinda } 1 \\
\text { Level } 2 \text { of Santana } \\
1 \text { (and level } 5 \text { from } \\
\text { Nova Olinda quarry } 1 \text { ) }\end{array}$} & \multirow{2}{*}{$\begin{array}{l}\text { Santana } 2 / \text { Nova } \\
\text { Olinda } 1 \\
\text { Level } 3 \text { of Santana } 2 \\
\text { (and levels 1-4 from } \\
\text { Nova Olinda quarry 1) }\end{array}$} & \multirow{2}{*}{$\begin{array}{l}\text { Nova Olinda } 3 \\
\text { Levels } 6 \text { and } 7\end{array}$} \\
\hline & & & & & \\
\hline $\begin{array}{l}\text { General character- } \\
\text { istics }\end{array}$ & Preservation & Good & Good & Good & Good \\
\hline \multirow[t]{9}{*}{ Macrostructure } & Lateral continuity & Discontinuous & Continuous & Discontinuous & Discontinuous \\
\hline & $\begin{array}{l}\text { Proximity between } \\
\text { structures }\end{array}$ & Close to contiguous & Close & Isolated & Isolated \\
\hline & $\begin{array}{l}\text { Connection between } \\
\text { structures }\end{array}$ & Coalescent & Coalescent & - & - \\
\hline & $\begin{array}{l}\text { Synoptic relief (con- } \\
\text { tinuous structures) }\end{array}$ & - & $\begin{array}{l}\text { Low relief continuous } \\
\text { domes }\end{array}$ & - & - \\
\hline & $\begin{array}{l}\text { Shape (discontinuous } \\
\text { structures) }\end{array}$ & Pseudo-columnar & Dome & Dome & Dome \\
\hline & Section contour & $\begin{array}{l}\text { Elliptic to equidimen- } \\
\text { sional, intergrown }\end{array}$ & $\begin{array}{l}\text { Elliptic to equidimen- } \\
\text { sional }\end{array}$ & Equidimensional & $\begin{array}{l}\text { Elliptic to equidimen- } \\
\text { sional }\end{array}$ \\
\hline & Branch & No & No & No & No \\
\hline & Edges & Coalescent & Rounded in plan-view & Rounded in plan-view & Rounded in plan-view \\
\hline & Vertical growth vector & Straight & Curved & Straight & Straight \\
\hline \multirow[t]{6}{*}{ Mesostructure } & Profile convexity & High & Low to moderate & Low & Moderate to high \\
\hline & Curvature order & Second & First & First & First \\
\hline & Laminar inheritance & Moderate to high & High & High & High \\
\hline & Symmetry & Symmetric & $\begin{array}{l}\text { Asymmetric to sym- } \\
\text { metric }\end{array}$ & Symmetric & Symmetric \\
\hline & $\begin{array}{l}\text { Internal discontinui- } \\
\text { ties }\end{array}$ & Absent & Absent & Absent & Absent \\
\hline & Laminae inflection & No & No & No & No \\
\hline \multirow[t]{5}{*}{ Microstructure } & Mineralogy & Calcite & Calcite & Calcite & Calcite \\
\hline & Texture & $\begin{array}{l}\text { Microsparitic to } \\
\text { sparitic }\end{array}$ & $\begin{array}{l}\text { Microsparitic to } \\
\text { sparitic }\end{array}$ & $\begin{array}{l}\text { Microsparitic to } \\
\text { sparitic or clotted }\end{array}$ & $\begin{array}{l}\text { Microsparitic to } \\
\text { sparitic }\end{array}$ \\
\hline & Porosity & Fenestral & Vuggy/Fenestral & Vuggy/Fenestral & Vuggy \\
\hline & Framework & Flat lamination & Flat lamination & $\begin{array}{l}\text { Flat/irregular lamina- } \\
\text { tion }\end{array}$ & Flat lamination \\
\hline & Diagenetic features & Recrystallization & Partly recrystallization & Oxidation & Partly recrystallization \\
\hline
\end{tabular}

List of morphological features modified from Fairchild et al. (2015), with additions from Hofmann (1969), Preiss (1972), Walter (1972), and Grey (1989). The table lists the microbial levels 1-3 from Santana and levels 1-7 in the Nova Olinda quarries. Level 2 from Santana quarry has the same morphology as Level 5 in the Nova Olinda quarry. Level 3 of Santana Quarry exhibits the same morphology as levels 1-4 of the Nova Olinda quarry

towards the top of the mounds, a feature also observed in the mounds at the Santana quarries. For example, a bundle of laminae measuring $10 \mathrm{~mm}$ in thickness close to the base of the slope of a mound increases to $19 \mathrm{~mm}$ at the top.

The distance between Level 3 and Level 4 is $70 \mathrm{~cm}$. Mounds in Level 4 reach up to $5.5 \mathrm{~cm}$ in height and have a lateral extension of $8-16 \mathrm{~cm}$ (Fig. 8c), those in Level 3, reach $9 \mathrm{~cm}$ in height and $70 \mathrm{~cm}$ in length, are elongated, irregular and are arranged parallel to each other. In general, microbialite levels 1-4 observed in Nova Olinda Quarry 1 closely resemble those observed in Level 3 from Santana quarries (Figs. 7, 8a-c; Table 2). An approximately 35-cmthick unit of horizontal laminites separates levels 4 and 5 . Level 5 consists of sparse domes with low relief (Fig. 8d). The lamination has a straight vertical growth (different from Level 2 in Santana Quarry 1) and a low to moderate convexity profile.

In Nova Olinda Quarry 3, in the northeastern part of the outcrop belt of the Crato Formation, there are two levels of gigantic domes (levels 6 and 7) (Fig. 10). The stromatolitic 


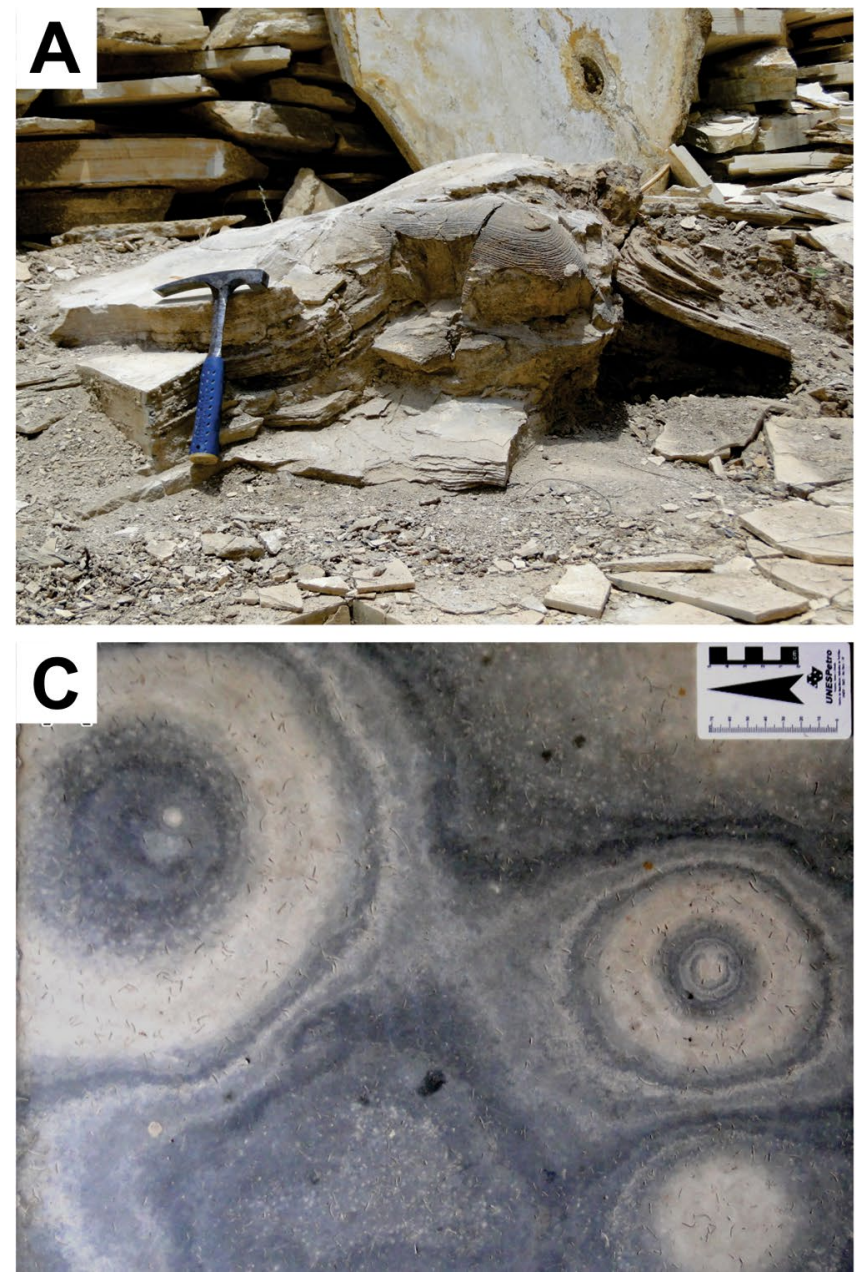

Fig. 4 a Small, isolated, and thinly laminated irregular dome located at the base of the exposed laminated limestone unit of the Santana Quarry 1 (level 1). b-d Plan-views of polished slabs of domal stro-

mound of Level 6 has a height of up to $80 \mathrm{~cm}$ and a length of $140 \mathrm{~cm}$ and corresponds to Level 3 in the Santana quarries. The discontinuous domes in Level 7 exhibit a straight vertical growth vector and a moderate-to-high profile convexity, which increases towards the top. The structures are about $100 \mathrm{~cm}$ high and $160 \mathrm{~cm}$ long (Fig. 10d). It is important to note that Level 7 occurs intercalated between an undulated laminated succession in the Nova Olinda Section and has no stratigraphic equivalent in the Santana succession (Fig. 2c).

\section{Microscopic and ultrastructural features}

Microscopic investigations were carried out mainly on samples from the Santana quarries. The main micromorphology seen in thin-sections is parallel and smoothly convex-up lamination (Fig. 11a-d). Lamination consists of alternations of dark and light laminae (each less
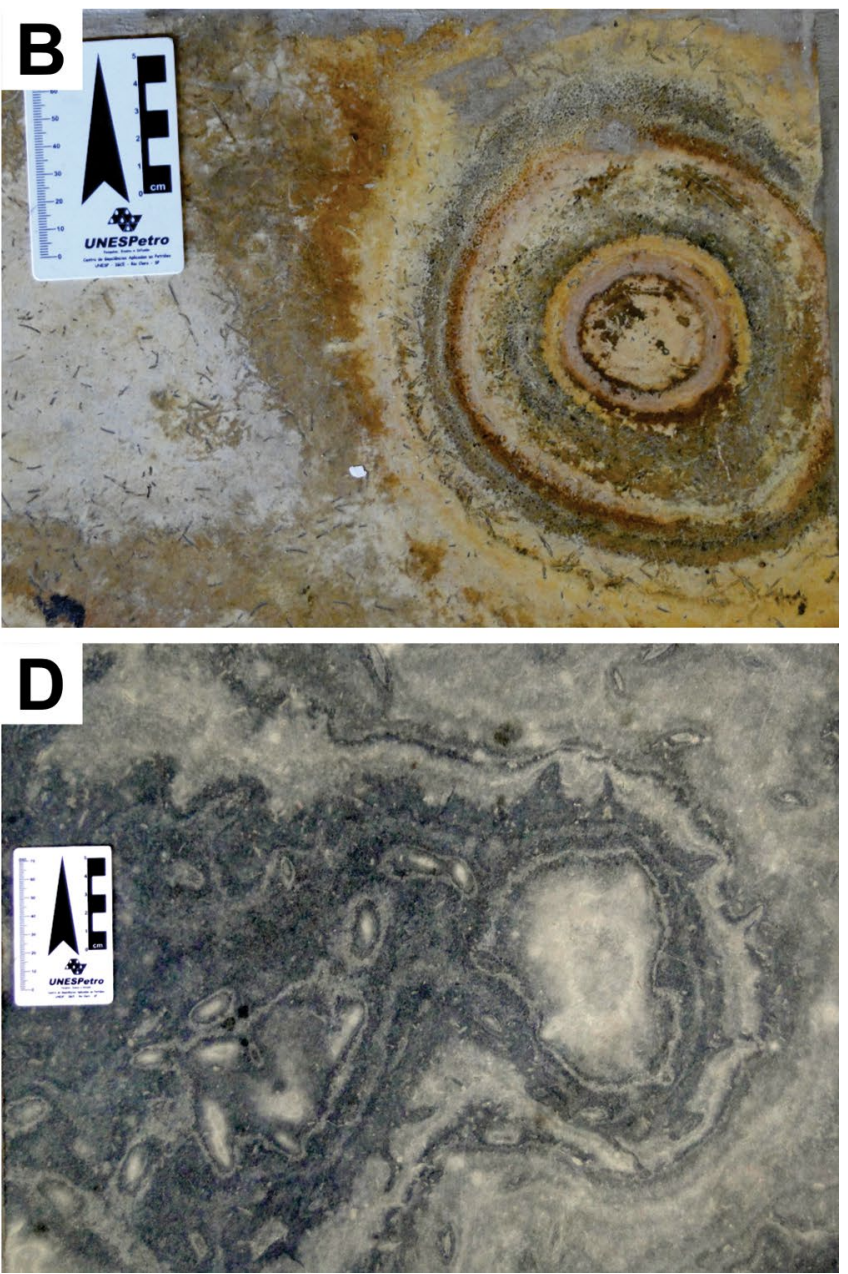

matolitic structures exhibiting thin concentric lamination. Locality unknown. c Note the two coalescent domes. d Detail of an irregular dome surrounded by centimeter-sized oval oncoids

than $0.5 \mathrm{~mm}$ in thickness; Fig. 11a), reflecting different degrees of calcite crystallization, mostly in the form of microsparite.

Peloids are abundant and occur dispersed in the lamination of the domes. The matrix is formed by euhedral to subhedral calcite micro-rhombohedra associated with filaments with diameter varying between 10 and $200 \mu \mathrm{m}$. The individual crystals are between 2 and $14 \mu \mathrm{m}$ in diameter, surrounded by honeycomb-like structures. Dark-colored organic matter is apparently preserved discontinuously between carbonate laminae (Fig. 11b; Catto et al. 2016). Millimeter- to centimeter-scale fenestral pores follow the lamination. The honeycomb-like internal structures, consisting of calcite, occur as micrometric laminae (Fig. 6a). Each of several individual empty chambers in this structure exhibits a circular shape. Their size ranges from 5 to $30 \mu \mathrm{m}$ (Fig. 6b). Other spherical calcite objects have also the same size and morphology (Fig. 6c). 


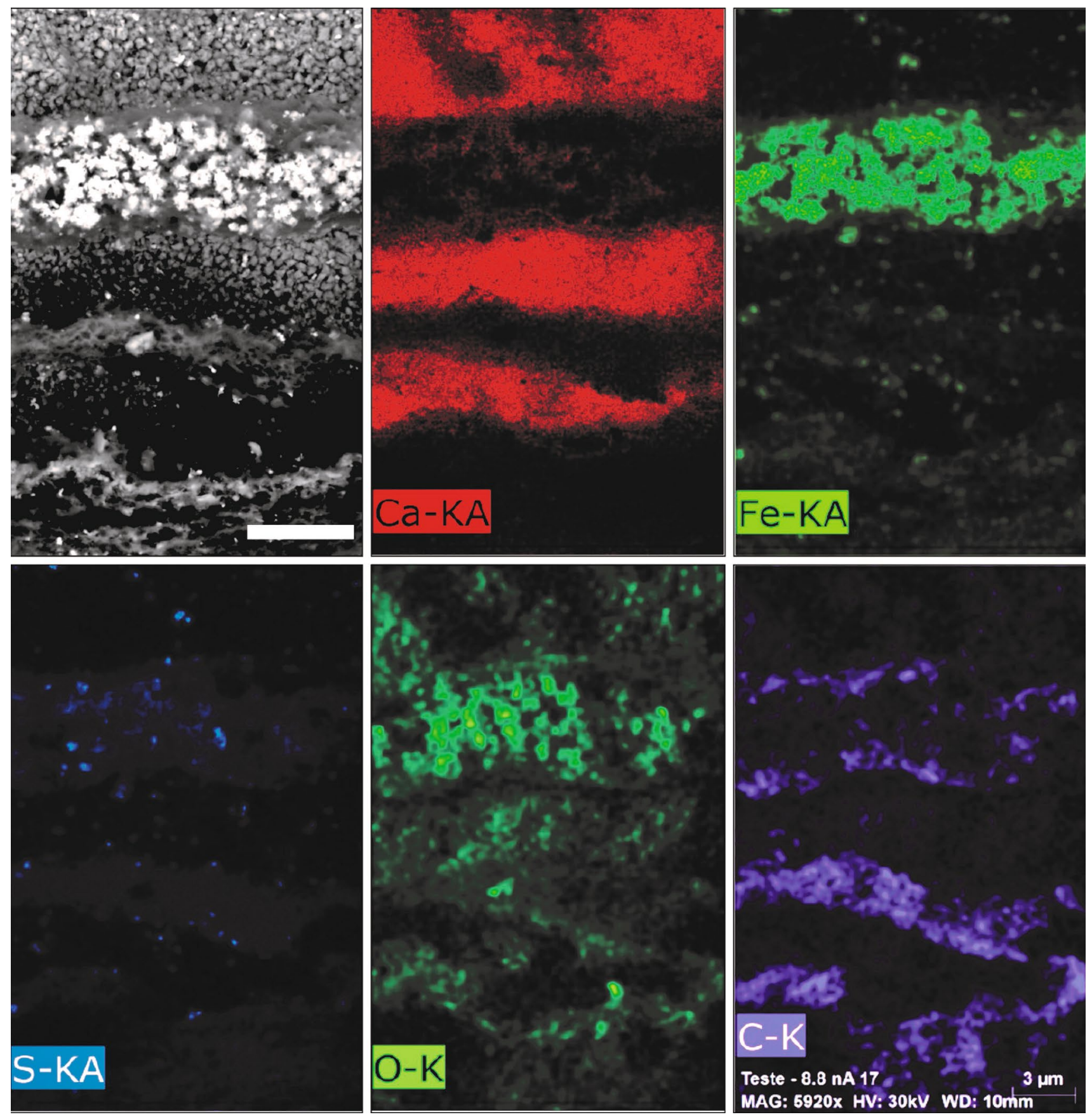

Fig. 5 Microfluorescence map of a microbialite sample from the Crato Formation (see detail of the organic matter in Fig. 6a). Note the high calcium and low carbon content in the light laminae, whereas

EDS and micro-fluorescence analysis were carried out in a microbialite sample from Level 2 and reveal a high content of carbon associated with dark organic-rich layers (Fig. 5). These organic layers are associated with oxidized pyrite with low levels of sulfur and higher concentrations of oxygen and iron. The low content of carbon in the calcite layers and high concentration in the organic layers indicate in the dark laminae carbon shows high concentrations (27.76 wt \%; $\left.C_{\text {organic }}>\mathrm{CaCO}_{3}\right)$. Scale bar is $5 \mu \mathrm{m}$

that $27.76 \mathrm{wt} \%$ of carbon in the sample is directly related to organic carbon.

The morphology of these very well preserved microstructures (honeycombs, spherical objects) suggests that they may represent calcified remains of original organic structures associated with benthic microbial communities, most likely EPS layers and coccoidal cells. The rhombohedral 

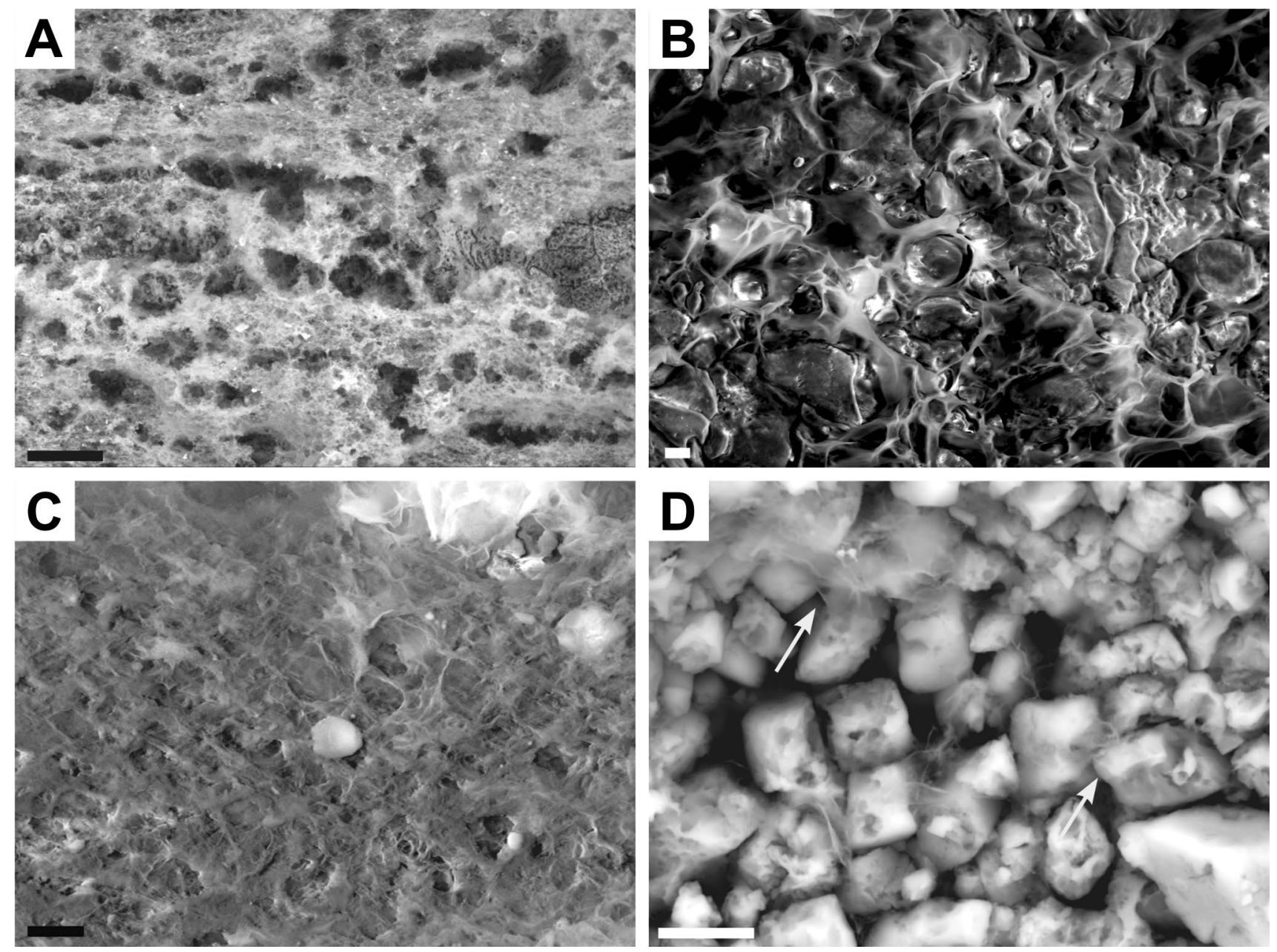

Fig. 6 Scanning electron micrographs of biogenic structures of the domal microbialites from the Crato Formation (from Catto 2015). a Sample of laminated carbonate showing multiple layers of calcified presumable EPS matrix. b Detail of calcified honey-comb structure interpreted as EPS. Note the spherules which are interbedded within the honey-comb structure and are interpreted as coccoidal bacterial cells. c Preserved coccoidal cell within the presumed EPS framework. d Calcite rhombohedra showing filaments interpreted as fila-

crystals are encompassed by what appears to be calcified EPS matrix. The calcareous filaments resemble filamentous bacterial cells and surround the calcite rhombohedra (Fig. 6d). The morphology of the rhombohedra and their association with calcified EPS suggest that the crystals are authigenic and a product of biologically induced mineralization (Dupraz et al. 2009). However, rhombohedral calcite crystals may also form as purely inorganic precipitates (e.g., Reeder 1983; Cizer et al. 2008; Montes-Hernandez et al. 2011; Rodriguez-Blanco et al. 2011). The size of the crystals shown in Fig. 6d is larger than average micrite crystals. Thus, their association with calcified EPS remains and the high-carbon content associated with the dark organic-rich mentous cyanobacteria cells and silicified EPS matrix between the euhedral crystals (arrowed). The smooth rhombs are interpreted as an organomineral product of biologically induced mineralization (sensu Dupraz et al. 2009). This image corresponds to a detail of organicrich laminae of a domal stromatolite from Level 2 at Santana (see Fig. 2). The scale bar is $100 \mu \mathrm{m}$ in a, and $10 \mu \mathrm{m}$ in b-d. a-c are from a core of the laminated carbonate unit at Nova Olinda Quarry 1

Fig. 7 Features of the domal microbialites from Level 2, Santana Quarry 1. a Note the presence of cavities in the strata bearing the microbialites. b Schematic representation of a. c Lateral view of Level 2 showing at least two medium-sized domes intercalated between flat-laminated carbonates. d Polished slab of domal structure. Note the convex-up lamination and the alternation of dark (organic-rich?) and light (more calcareous) laminae packages. e Detail of $\mathbf{c}$ showing a low-relief medium-sized domal structure. The hammer in all pictures is $25 \mathrm{~cm}$ long. The scale bar in $\mathbf{c}$ is $10 \mathrm{~cm}$, in d and $\mathbf{e} 5 \mathrm{~cm}$

layers may suggest a microbial origin. The fenestral pores possibly represent gas escape structures from the metabolic activity of benthic microbes living in the domes. 

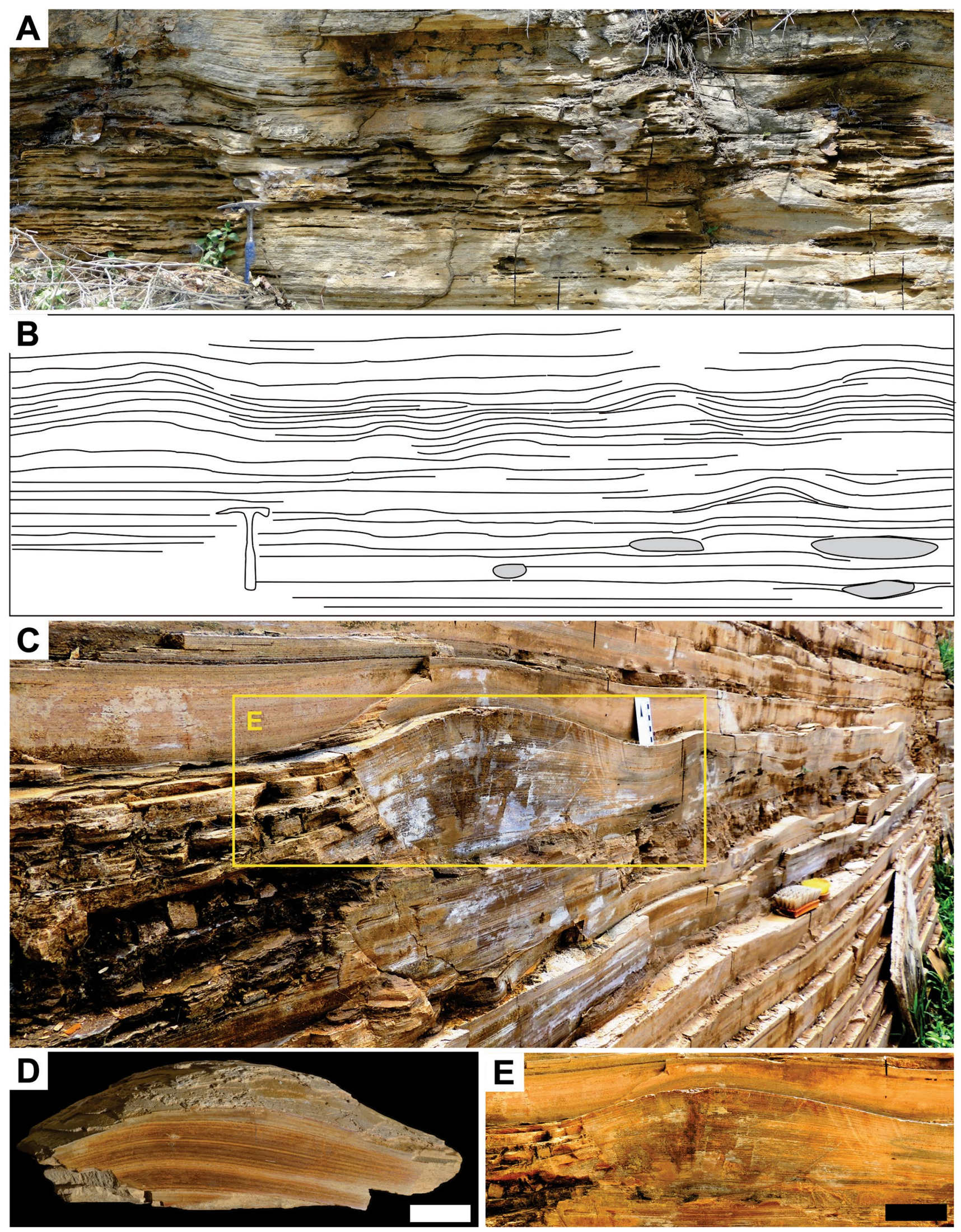


\section{Adaptation of microbialites to high-stress environments}

Different types of microbes, including cyanobacteria, play an important role in carbonate production from the Archean to the Present (e.g., Riding 2000). Microbes show a broad environmental tolerance (e.g., Whitton and Potts 2000; Mohr et al. 2011). This tolerance and high adaptability allows them to thrive in environments with high salinity and temperature as well as drastic $\mathrm{pH}$ oscillations (Decho 2000). In contrast, such stressful settings are unsuitable for the vast majority of metazoans (Des Marais 1995).

The protection provided by the EPS is essential for microbial communities to attach to the substrate, resulting in generations of micro-domains that allow microbes with different types of metabolisms to coexist (Decho 2000). The EPS also helps the microbialites to resist stressful conditions by stabilizing them against strong hydrodynamic regimes (Decho et al. 2005) and high salinity, alkalinity, and temperature (Kremer 2006). The degradation of EPS plays a key role in the precipitation of carbonate minerals, acting as a mechanism that increases the alkalinity of the environment, due to the metabolism of sulfate-reducing bacteria (Visscher et al. 2002; Braissant et al. 2007). In addition, Reitner (2011) and Arp et al. (2012), while studying hypersaline lakes on Christmas Island (Kiritimati), documented the role of photosynthesis and exopolymer degradation for microbialite formation. The metabolic and photosynthetic activity of some types of microbes also elevate alkalinity in the environment, increasing the inorganic carbon dissolved and calcium carbonate saturation, forcing its precipitation (Dupraz et al. 2009). In the same way, the close relationship between different microbial communities and stromatolite microstructures (Farías et al. 2011, 2013) was recently documented in Socompa Lake, a high altitude (3570 m), alkaline, hypersaline lake on the Argentine Andean plateau with profuse carbonate stromatolite growth. The microbial communities live in a very shallow lake subject to high chemical and physical stress, such as wide fluctuations in daily temperatures, hypersalinity, alkalinity, and high level of UV radiation.

\section{Depositional and paleoenvironmental implications}

\section{Source of carbonates and origin of mounds and domes}

In the last decades, the origin of laminites in the Crato Formation was an issue of broad interest for the geological community focusing on this world-famous FossilLagerstätte. Based on some inconclusive features, such as vugs, smooth convex-up, ripple-like microbial mats (wrinkle marks?), and slumped and brecciated laminae, some authors suggested a microbial influence for the origin of the laminated facies (e.g., Heimhofer and Martill 2007; Martill et al. 2007b). The presence of oncoids was noticed also by Heimhofer and Martill (2007, Fig. 4f) in the Crato Formation, but according to these authors, these microbialites are unusual and rare.

The micro-ripple-like lithified structures described by Heimhofer and Martill (2007) and similar structures found by us in several levels of Nova Olinda Quarry 2, corresponding to the stromatolite levels 1-4 of Nova Olinda Quarry 1 (Fig. 9), are indeed best interpreted as of microbial origin. In our opinion, the compatible scale and the presence of elongate and bifurcated crests with flat tops separated by shallow depressions, strongly resemble wrinkle structures such as Kinneyia (Porada et al. 2008). Wrinkled surfaces are generally interpreted as irregular surfaces of microbial mats or to have formed by the deformation of mats by currents and waves (Hagadorn and Bottjer 1997).

Contrary to the observations above, Heimhofer et al. (2010) argued that the whole laminated limestone succession was generated by authigenic precipitation of calcite crystals that was induced by biochemical processes without any "significant carbonate contribution from a benthonic microbial community". The authors interpreted that precipitation of calcite occurred in the hypersaline water column, and was mediated by biochemical processes. Thus, according to these authors microbial-induced carbonate production at the lake floor apparently played only a very minor role. Contrarily, Catto et al. (2016) highlighted the microbial influence in the formation of the laminated limestones of the Crato Formation. His interpretation was based on the presence of (a) abundant calcified coccoid and filament cells, including the cyanobacteria Spirulina, (b) calcified biofilms composed of extracellular polymeric substances (EPS), and (c) the occurrence of calcitic filaments and micro-rhombohedra within calcified EPS interpreted as a product of biological-induced mineralization sensu Perry et al. (2007) and Dupraz et al. (2009). In accordance with the evidence presented by Catto et al. (2016), the stromatolite structures described here clearly point to biologically induced mineralization within the limestone interval of the Crato Formation. Our findings suggest that within the main carbonate unit repeatedly favorable conditions existed for the growth of microbial communities at the lake floor. Poor oxygenation and high salinity (attested by abundant pyrite crystals, halite hopper crystals and other salt pseudomorphs) prevailing during the deposition of the Crato Formation (see also Heimhofer et al. 2010) apparently precluded the presence of grazing benthos but not of microbial colonies. The presence of calcified remains of microbial cells of probable cyanobacteria affinity suggests that the microbial levels formed in relatively shallow waters setting within the photic zone.

The microbialites of the Crato Formation strongly resemble the stromatolites occurring in the present-day 

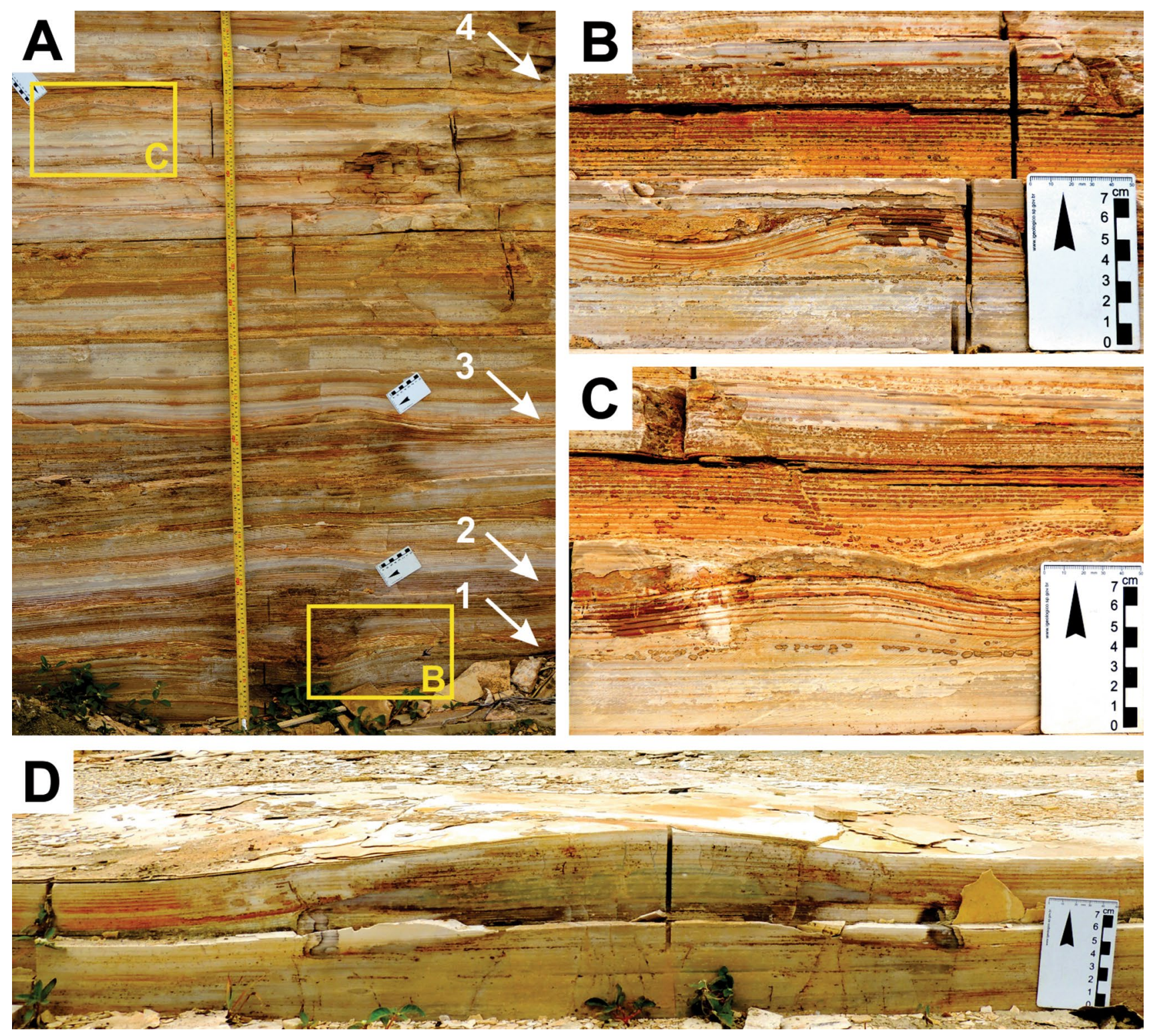

Fig. 8 Microbialites from Nova Olinda Quarry 1. a Succession of laminated limestones showing the presence of at least four stromatolite microbialite levels. The white arrows indicate the base of each microbialite level. b Detail of small domal structure from Level
1 in a. c Detail of low-relief domal structure from Level 4 in a. d 3-D view of domal structure showing the smooth convex-up laminae directly overlying horizontal laminites. The scale bar in $\mathbf{a}-\mathbf{d}$ is $8 \mathrm{~cm}$
Socompa lake of the Andes (Farías et al. 2011), which consist of broad, low domes, rounded to oblong in plant view and are composed of smooth laminae. Neighboring domes tend to coalesce into bigger domes, some of which are also elongated as in the case of the Crato Formation. In several cases the laminae within the mounds and domes can be traced into the neighboring flat lake floor, producing a striking similarity between the lamination of the microbial structures and the remaining lamination of the carbonates. This suggests a common origin of laminae, which might lead to the interpretation that in fact the whole lake floor was occasionally covered by microbial films. This assumption has far-reaching consequences for the interpretation of the excellent preservation of fossils within the laminated limestones (see below). This hypothesis needs, however, to be substantiated by further detailed investigation of the micro-and nanofacies of the flat-laminated carbonates.

As already mentioned above, Heimhofer et al. (2010) convincingly argued that small calcite rhombohedra originating in the upper water column form the bulk of the finely laminated carbonates. When settling, these grains accumulated on both mounds/domes and on the flat lake floor. The 

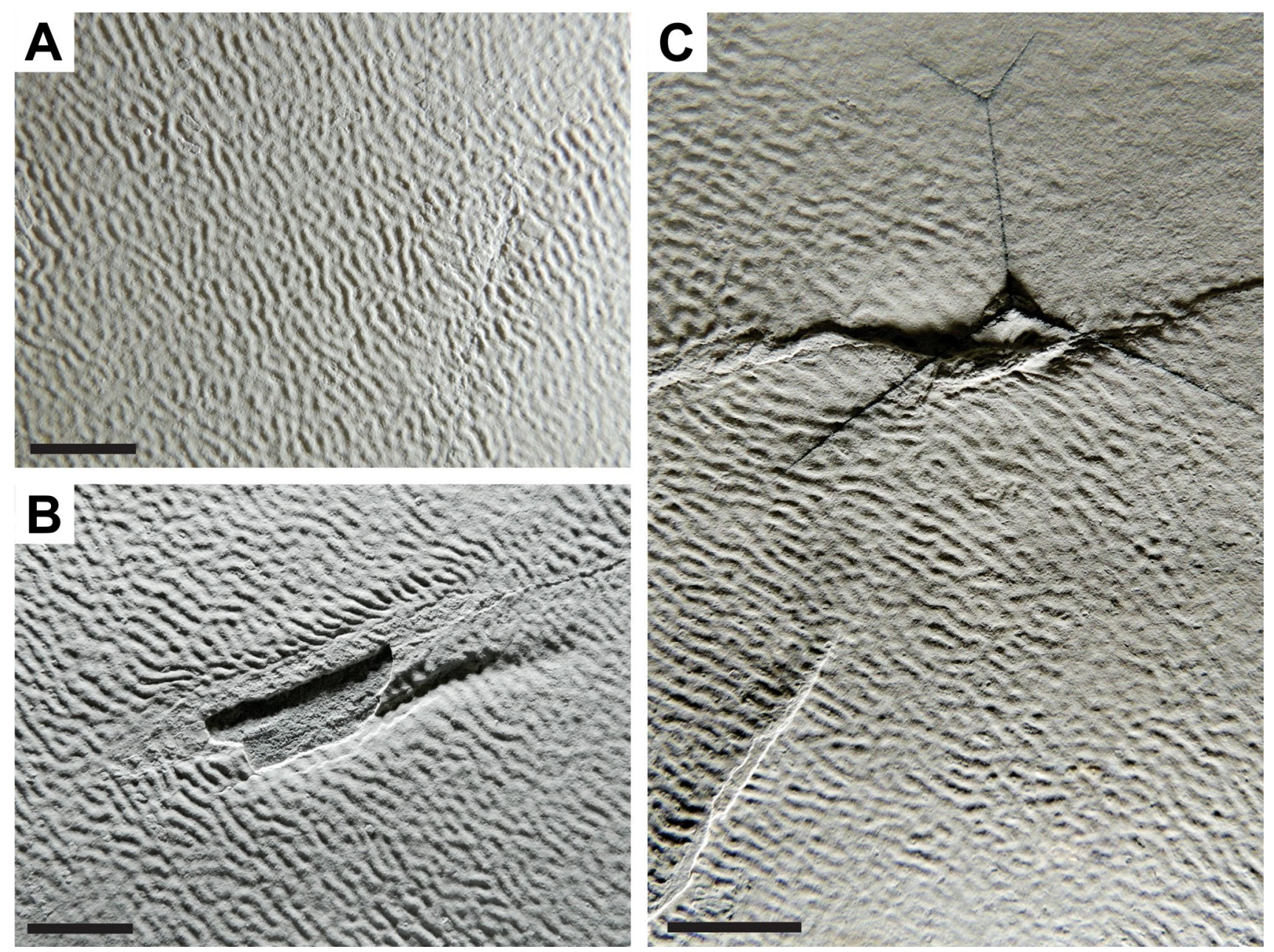

Fig. 9 a-c Kinneyia-type wrinkle structures (sensu Porada et al. 2008) at the Nova Olinda Quarry 2. The radial cracks in c have been caused by incipient growth of halite crystals. The scale bar in $\mathbf{a}-\mathbf{c}$ is $1 \mathrm{~cm}$

difference between the two bottom morphologies (flat versus domal) consists in the greater thickness of the laminae within the latter. The most obvious explanation for this is the binding capacity of the microbial mat, which produced the stromatolite structures, probably associated with microbial-induced early cementation. This cementation may also have prevented compaction of these elevated structures in contrast to the surrounding flat areas. However, it appears that compaction played only a limited role within the lake carbonates judging from the originally high porosity of the regular laminated carbonates (now partly filled with carbonate cements, Heimhofer et al. 2010).

\section{The Crato lake: a Cretaceous analogue of the modern hypersaline lakes of the Kiritimati Atoll?}

On the Kiritimati Atoll, Christmas Islands, central Pacific Ocean, several small, very shallow hypersaline lakes exist, the bottoms of which are covered with profuse microbial mats (Trichet et al. 2001; Saenger et al. 2006; Reitner 2011; Arp et al. 2012). Some of these lakes are connected to a large lagoon $\left(190 \mathrm{~km}^{2}\right)$ (Saenger et al. 2006). The lakes are characterized by a high variability of environmental parameters, such as oxygen, $\mathrm{pH}$, and salinity that strongly restrict the diversity of the biota. The microbial communities were studied in detail by Reitner (2011) and Arp et al. (2012). According to them, the microbialite formation by carbonate precipitation takes place in the lower parts of the mats as a result of exopolymers degradation (see also Défarge et al. 1996).

The position of these lakes close to marine environments and the presence of laminated carbonates, evaporites, abundant benthic microbial communities, lithified microbialites, anomalous and variable salinities (Trichet et al. 2001; Saenger et al. 2006; Reitner 2011; Arp et al. 2012), as well as events of fish mass-mortality (Reitner 2011) closely resemble features that are characteristic of the Crato lake carbonates. However, there are also key differences 

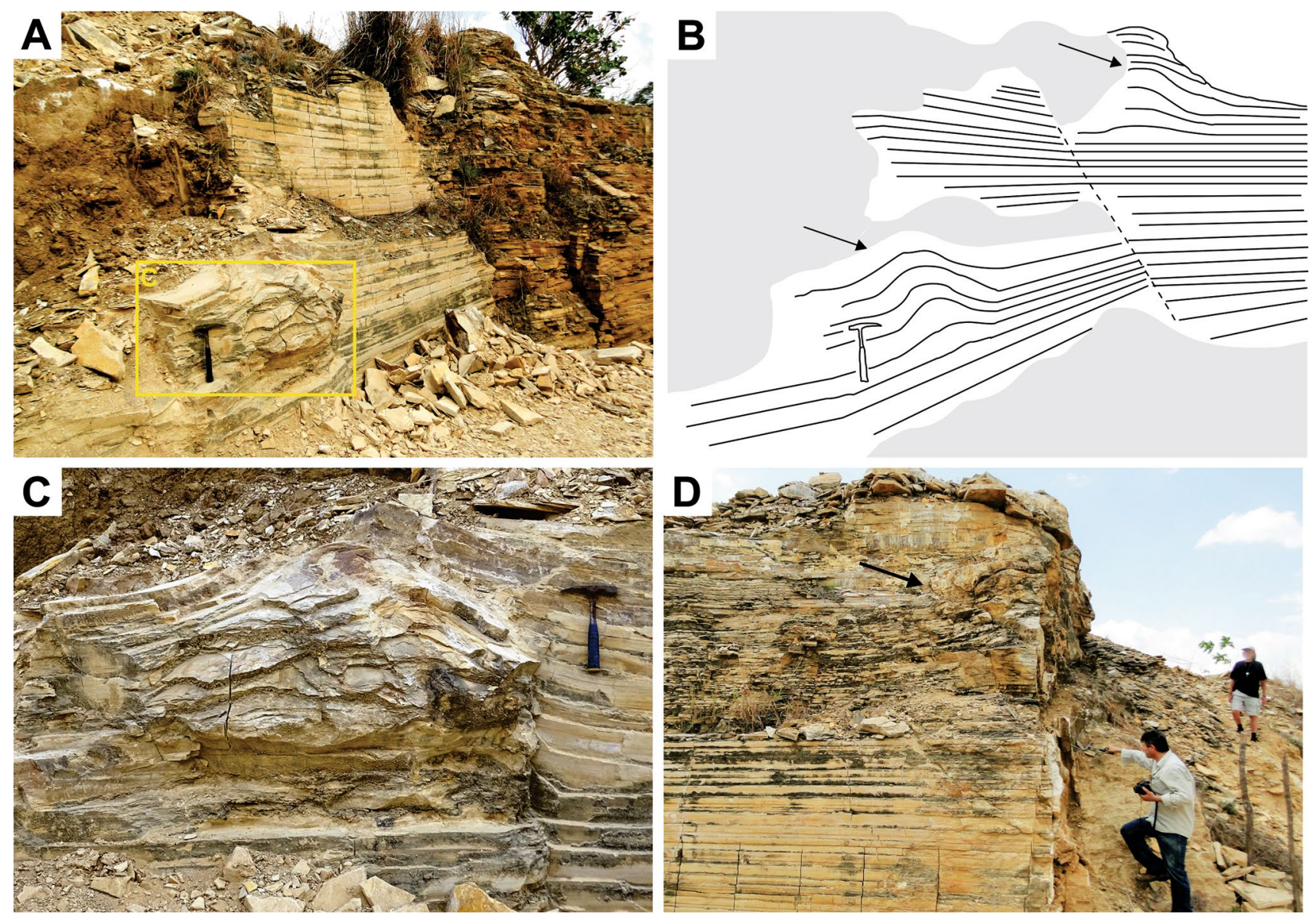

Fig. 10 a-d Giant stromatolite domes from levels $6(\mathbf{a}-\mathbf{c})$ and $7(\mathbf{d})$ at Nova Olinda Quarry 3. b Sketch of the structure in a. c Detail of the stromatolite in $\mathbf{a}$

between the fossil and the modern analogue. For example, microbial mats were not as prominent in the Crato lake. Moreover, the precipitated carbonate minerals in the Crato lake apparently were calcitic, rather than aragonitic, as in the case of Kiritimati lake. Finally, the investigated Crato sediments (especially the limestones) do not exhibit any signs of intertidal to supratidal environments. Nevertheless, it appears that in both lake systems many environmental parameters were similar and characterized by microbial communities, even though in the Crato lake microbialites occurred only locally at certain levels.

\section{The role of microbialites for excellent fossil preservation}

The presence of microbialites in the Crato Formation raises the possibility that microbial mats played a decisive role in the excellent preservation of the fossils of this unit (Martill 1988; Martill et al. 2008; Barling et al. 2015). In the main carbonate unit of this formation $(\sim 10 \mathrm{~m}$ of fossil-bearing laminites; Martill and Bechly 2007), fossils are preserved in two distinct modes: (1) as goethite/limonite replacement, and (2) as phosphatized remains (Menon and Martill 2007). Martill et al. (2008) argued that occasional mass mortality events were a prerequisite for the formation of the Konservat-Lagerstätte. According to them, these drastic events occurred in response to changes in water oxygenation and salinity, poisoning of the water by $\mathrm{H}_{2} \mathrm{~S}$ released from reducing bottom sediments, or by cyanobacterial blooms. The best-preserved organisms are phosphatized (Menon and Martill 2007; Barling et al. 2015). The origin of the phosphorous is still controversial, but this compound may be derived from microbial degradation and concentration in the water column (Wilby et al. 1996).

Regardless of the origin of organic phosphorus, the confirmed microbial-influenced/induced carbonate mineralization most likely played a key role in fossil preservation (Martill 1988; see also Wilby et al. 1996; Iniesto et al. 2013; Raff et al. 2014). The presence of microbial mats covering the bottom would have prevented the carcasses from floating in the water column. Furthermore, the rapid growth of the microbial mats would have protected them 

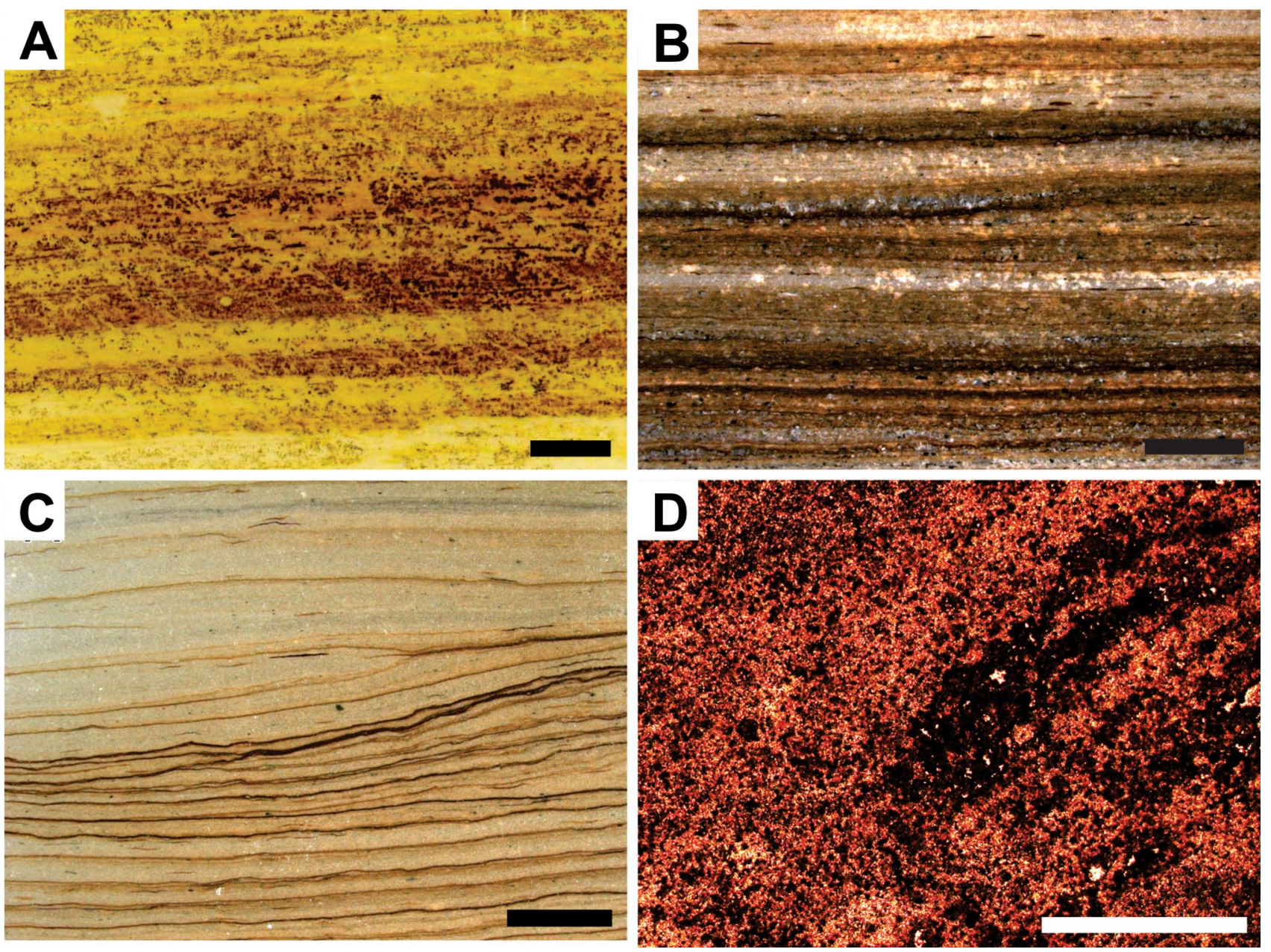

Fig. 11 Thin-section micrographs of the microbialites from the Crato Formation. a Detail of the alternation between yellow and brown laminae, Level 2, Santana Quarry 1; ×50, parallel polarizers. b Close-up of the thin lamination; $\times 25$, crossed polarizers). c Convex up lamination of low-relief dome, Level 3, Santana Quarry 1, and detail of

truncated laminations; $\times 25$, parallel polarizers. $\mathbf{d}$ Detail of $\mathbf{c}$; note the presence of several small $(<30 \mu \mathrm{m}$ in diameter $)$ circular objects, which may represent the remains of original organic structures; $\times 50$, crossed polarizers. The scale bar is $2 \mathrm{~mm}$ in $\mathbf{a}-\mathbf{c}$ and $0.5 \mathrm{~mm}$ in $\mathbf{d}$

from scavengers and bioturbators (Wilby et al. 1996). The fact that microbial mats are sites of rapid mineralization also may have accelerated this process (Chafetz and Buczynski 1992). Another important factor for the preservation of organic material is the absence of oxidizing conditions a few millimeters below the surface of the mats caused by the degradation of cells and EPS.

The preservation of organisms with organic skeletons (arthropods, plants etc.), and the complete absence of bottom-dwelling benthos and bioturbation structures is a prominent feature of the Crato Lagerstätte (Maisey 1991). The lack of grazing benthos, such as gastropods in this stratigraphic interval may have contributed to the proliferation of the microbial mats. Hence, the microbial communities may have played direct and indirect roles in the exceptional preservation of the Crato fossils, which arrived at the lake bottom from the water column.

Barling et al. (2015) recorded microfabrics (i.e., microspheres, hollow micro-spheres and aggregates) in insect fossils of the Crato Formation, which may represent bacterially mediated $\mathrm{Fe}$ mineral growths. According to these authors, some may even represent auto-lithified bacteria (Barling et al. 2015). Indeed, the high preservational fidelity of the Crato fossils, which is comparable to that of typical Ediacaran fossil embryos where the microbial activity promoted the direct replication of tissues by apatite, may be linked to substrate microbial fabrics (Briggs and McMahon 2016). Thus, biogeochemical processes involving mineralization of organic remains by microbial colonies seem to be essential for the preservation of Crato fossils. The lack of bacterial decay of organic skeletons and tissues in the laminated limestones of the Crato Formation could be associated with microbial communities that thrived on an anoxic, hypersaline bottom, since these conditions can contribute 
to slowdown of decay (Fürsich et al. 2007). This process is common in hypersaline lakes (e.g., Maisey 1991). Additionally, microbial films may have had the direct effect of sealing the substrate, protecting organisms from any disturbance and from rapid, complete decay, in a manner similar to that described by Gehling (1999) for large Ediacaran body fossils (Briggs and McMahon 2016, p. 5). Indeed, this feature appears to have played a major role in the excellent preservation of fossils in a number of other laminated lagerstätten, such as the Upper Jurassic Solnhofen plattenkalks of southern Germany (Keupp 1977), and the Early Cretaceous lake deposits of northeastern China (Fürsich et al. 2007).

\section{Concluding remarks}

This contribution provides evidence for biologically induced carbonate mineralization in the most important South American Cretaceous Fossil-Lagerstätte. During the Aptian, microbial mats locally thrived in quiet, shallow-water, hypersaline, and oxygen-deficient settings at the margins of the Araripe lacustrine system, and were responsible for the origin of stromatolite mounds and domes. This finding, together with macro-, meso-, and microscopic evidence (in situ coccoidal, filamentous, and spiral cyanobacteria cells and fossilized extracellular polymeric substances, see Catto et al. 2016) indicate that the genesis of the well-laminated limestone, corresponding to the main fossil-bearing interval of the Crato Formation, was indeed strongly influenced by microbial activity. The extreme paleoenvironment accounted for the absence of bottom-dwelling benthos, favoring the profuse development of microbial mats and preservation of the organic remains.

The discovery of stromatolitic microbialites in the finely laminated limestones of the lower Crato Formation provides a unique opportunity to address the direct and indirect roles of the microbial communities in the exceptional preservation of the Crato fossils, and would be an important new research avenue for future taphonomic investigations of this Konservat-Lagerstätte.

Acknowledgements We are deeply indebted to Pablo Suarez-Gonzalez, Universidad Complutense de Madrid, for his very constructive comments on an earlier version of this manuscript. The reviews by Eduardo Roemers-Oliveira and an anonymous reviewer are also gratefully acknowledged. The authors thank Suzana Aparecida Matos da Silva for assistance in the field and photography. Financial supported by CNPq (Grants 444070/2014-1, 401039/2014-5, 30017/20153), FAPESP (Grant 2014/27337-8, 2004/15786-0) and Petrobras (0050.0023165.06.4) is gratefully acknowledged. We also thank the Center for Geosciences Applied to Petroleum Geology, São Paulo State University (UNESPetro-UNESP), for the laboratory facilities for Scanning Electron Microscopy, petrographic macroscopy and magnifier stereoscopy. This research was conducted with institutional support of the São Paulo State University-UNESP, Brazil. Assine, M.G. Simões and L.V. Warren are fellows of the CNPq.

\section{References}

Arp G, Helms G, Karlinska K, Schumann G, Reimer A, Reitner J, Trichet J (2012) Photosynthesis versus exopolymer degradation in the formation of microbialites on the atoll of Kiritimati, Republic of Kiribati, Central Pacific. Geomicrobiol J 29:29-65. doi:10.10 80/01490451.2010.521436

Assine ML (1992) Análise estratigráfica da Bacia do Araripe, Nordeste do Brasil. Revista Brasileira de Geociências 22:289-300

Assine ML (2007) Bacia do Araripe. Boletim de Geociências da Petrobras 15:371-389

Assine ML, Perinotto JAJ, Neumann VH, Custódio MA, Varejão FG, Mescolotti PC (2014) Sequências Deposicionais do Andar Alagoas (Aptiano superior) da Bacia do Araripe, Nordeste do Brasil. Boletim de Geociências da Petrobras. 22(1):3-28

Assine ML, Quaglio F, Warren LV, Simões MG (2016) Comments on paper by M. Arai, "Aptian/Albian (Early Cretaceous) paleogeography of the South Atlantic: a paleontological perspective". Braz J Geol 46:3-7

Baez AM, Moura GJB, Gómez RO (2009) Anurans from the Lower Crato Formation of northeastern Brazil: implications for the early divergence of neobatrachians. Cretac Res 30:829-846

Barling N, Martill DM, Heads SW, Gallien F (2015) High fidelity preservation of fossil insects from the Crato Formation (Lower Cretaceous) of Brazil. Cretac Res 52 Part B 605-622. doi:http:// dx.doi.org/10.1016/j.cretres.2014.05.007

Barthel KW, Swinburne NHM, Conway Morris S (1994) Solnhofen: a study in Mesozoic palaeontology. Cambridge University Press, Cambridge

Benzerara K et al (2006) Nanoscale detection of organic signatures in carbonate microbialites. Proc Natl Acad Sci 103:9440-9445

Braissant O, Decho AW, Dupraz C, Glunk C, Przekop KM, Visscher PT (2007) Exopolymeric substances of sulfate-reducing bacteria: interactions with calcium at alkaline $\mathrm{pH}$ and implication for formation of carbonate minerals. Geobiology 5:401-411

Briggs DE, McMahon S (2016) The role of experiments in investigating the taphonomy of exceptional preservation. Palaeontology 59:1-11

Brito Neves BB, Santos EJ, Van Schmus WR (2000) Tectonic history of the Borborema Province, northeastern Brazil. In: Cordani UG, Milani EJ, Thomaz Filho A, Campos DA (eds) Tectonic evolution of South America. $31^{\circ}$ International Geological Congress, Rio de Janeiro, pp 151-182

Buick R, Dunlop JSR, Groves DI (1981) Stromatolite recognition in ancient rocks: an appraisal of irregularity laminated structures in an Early Archean chert-barite unit from North Pole, Western Australia. Alcheringa 5:161-181

Castro DL, Branco RMGC (1999) Caracterização da arquitetura interna das bacias do Vale do Cariri (NE do Brasil) com base em modelagem gravimétrica 3-D. Braz J Geophys 17:129-144

Catto B (2015) Laminitos microbiais no Membro Crato (Neoaptiano) da Bacia do Aararipe, nordeste do Brasil. Master dissertation, São Paulo State University

Catto B, Jahnert RJ, Warren LV, Varejão FG, Assine ML (2016) The microbial nature of laminated limestones: lessons from the Upper Aptian, Araripe Basin, Brazil. Sediment Geol. doi:10.1016/j. sedgeo.2016.05.007

Chafetz HS, Buczynski C (1992) Bacterially induced lithification of microbial mats. Palaios 7:277-293. doi:10.2307/3514973

Cizer Ö, Van Balen K, Elsen J, Van Gemert D (2008) Crystal morphology of the precipitated calcite crystals from accelerated 
carbonation of lime binders. In: 2nd International Conference on Accelerated Carbonation for Environmental and Materials Engineering, 2008. University of Rome "La Sapienza", Rome, pp 149-158

Decho AW (2000) Exopolymer microdomains as a structuring agent for heterogeneity within microbial films. In: Riding RE, Awramik SM (eds) Microbial sediments. Springer, Berlin, pp 1-9

Decho AW, Visscher PT, Reid RP (2005) Production and cycling of natural microbial exopolymers (EPS) within a marine stromatolite. Palaeogeogr Palaeoclimatol Palaeoecol 219:71-86. doi:10.1016/j.palaeo.2004.10.015

Défarge C, Trichet J, Jaunet A-M, Robert M, Tribble J, Sansone FJ (1996) Texture of microbial sediments revealed by cryo-scanning electron microscopy. J Sediment Res 66:935-947

Demicco RV, Hardie LA (1994) Sedimentary structures and early diagenetic features of shallow-marine carbonate deposits. Atlas series 1. Society of Economic Paleontologists and Mineralogists, Tulsa

Des Marais D (1995) The biogeochemistry of hypersaline microbial mats. In: Jones JG (ed) Advances in microbial ecology, vol 14, pp 251-274. doi:10.1007/978-1-4684-7724-5_6

Do Carmo DA, Whatley R, Neto JVQ, Coimbra JC (2008) On the validity of two lower Cretaceous non-marine ostracode genera: biostratigraphic and paleogeographic implications. J Paleontol 82:790-799

Dravis JJ (1983) Hardened subtidal stromatolites, Bahamas. Science 219:385-386. doi:10.1126/science.219.4583.385

Dupraz C, Reid RP, Braissant O, Decho AW, Norman RS, Visscher PT (2009) Processes of carbonate precipitation in modern microbial mats. Earth Sci Rev 96:141-162. doi:10.1016/j. earscirev.2008.10.005

Fairchild TR, Rohn R, Dias-Brito D (2015) Microbialitos do Brasil: do Pré-Cambriano ao Recente. UNEPetro, Rio Claro

Farías ME, Poiré DG, Arrouy MJ, Albarracin VH (2011) Modern stromatolite ecosystems at alkaline and hypersaline highaltitude lakes in the Argentinean Puna. In: Tewari V, Seckbach J (eds) Stromatolites: interaction of microbes with sediments. Springer Netherlands, Dordrecht, pp 427-441. doi:10.1007/978-94-007-0397-1_19

Farías ME et al (2013) The discovery of stromatolites developing at $3570 \mathrm{~m}$ above sea level in a high-altitude volcanic lake Socompa, Argentinean Andes. PLoS One 8:1-15

Fürsich FT, Sha J, Jiang B, Pan Y (2007) High resolution palaeoecological and taphonomic analysis of Early Cretaceous lake biota, western Liaoning (NE-China). Palaeogeogr Palaeoclimatol Palaeoecol 253:434-457

Gehling JG (1999) Microbial mats in terminal Proterozoic siliciclastics; Ediacaran death masks. Palaios 14:40-57

Grey K (1989) Handbook for the study of stromatolites and associated structures. Stromatolite Newsl 14:82-171

Grotzinger JP, Knoll AH (1999) Stromatolites in Precambrian Carbonates: evolutionary mileposts or environmental dipsticks? Annu Rev Earth Planet Sci 27:313-358

Hagadorn JW, Bottjer DJ (1997) Wrinkle structures: microbially mediated sedimentary structures common in subtidal siliciclastic settings at the Proterozoic-Phanerozoic transition. Geology 25:1047-1050

Heimhofer U, Hochuli P-A (2010) Early Cretaceous angiosperm pollen from a low-latitude succession (Araripe Basin, NE Brazil). Rev Palaeobot Palynol 161:105-126. doi:10.1016/j. revpalbo.2010.03.010

Heimhofer U, Martill DM (2007) The sedimentological and depositional environment of the Crato Formation. In: Martill DM, Bechly G, Loveridge RF (eds) The Crato fossil beds of Brazil: Window into an ancient world. Cambridge University Press, New York, pp 44-62
Heimhofer U, Ariztegui D, Lenniger M, Hesselbo SP, Martill DM, Rios-Netto AM (2010) Deciphering the depositional environment of the laminated Crato fossil beds (Early Cretaceous, Araripe Basin, North-eastern Brazil). Sedimentology 57:677-694. doi:10.1111/j.1365-3091.2009.01114.x

Hofmann H (1969) Attributes of stromatolites. Geol Surv Can Pap 69:58

Iniesto M, Lopez-Archilla AI, Fregenal-Martínez M, Buscalioni AD, Guerrero MC (2013) Involvement of microbial mats in delayed decay: an experimental essay on fish preservation. Palaios 28:56-66. doi:10.2110/palo.2011.p11-099r

Jahnke LL et al (2001) Signature lipids and stable carbon isotope analyses of Octopus Spring hyperthermophilic communities compared with those of aquificales representatives. Appl Environ Microbiol 67:5179-5189

Keupp H (1977) Ultrafazies und Genese der Solnhofener Plattenkalke (Oberer Malm, Südliche Frankenalb). Abhandlungen der Naturhistorischen Gesellschaft Nürnberg 37:1-128

Kremer B (2006) Mat-forming coccoid cyanobacteria from early Silurian marine deposits of Sudetes, Poland. Acta Palaeontol Pol 51:143-154

Mabesoone JM, Tinoco IM (1973) Paleoecology of Aptian Santana Formation (northeastern Brazil). Palaeogeogr Palaeoclimatol Palaeoecol 14:87-118

Magnavita LP, Cupertino JA (1987) Concepção atual sobre as Bacias do Tucano e Jatobá, Nordeste do Brasil. Boletim de Geociência da Petrobras 1:119-13416

Maisey JG (1991) Santana fossils_-an illustrated atlas. TFH Publishers, Neptune City, NJ

Makarkin VN, Menon F (2005) New species of the Mesochrysopidae (Insecta, Neuroptera) from the Crato Formation of Brazil (Lower Cretaceous), with taxonomic treatment of the family. Cretac Res 26:801-812

Marques F, Nogueira F, Bezerra F, de Castro D (2014) The Araripe Basin in NE Brazil: an intracontinental graben inverted to a highstanding horst. Tectonophysics 630:251-264

Martill DM (1988) Preservation of fish in the Cretaceous Santana Formation of Brazil. Palaeontology 31:1-18

Martill DM, Bechly G (2007) Introduction to the Crato Formation. In: Martill DM, Bechly G, Loveridge RF (eds) The Crato fossil beds of Brazil: window into an ancient world. Cambridge University Press, New York, pp 3-7

Martill DM, Bechly G, Loveridge RF (eds) (2007a) The Crato fossil beds of Brazil-window into an ancient world, 1st edn. Cambridge University Press, New York

Martill DM, Loveridge R, Heimhofer U (2007b) Halite pseudomorphs in the Crato Formation (Early Cretaceous, Late AptianEarly Albian), Araripe Basin, northeast Brazil: further evidence for hypersalinity. Cretac Res 28:613-620

Martill DM, Brito PM, Washington-Evans J (2008) Mass mortality of fishes in the Santana Formation (Lower Cretaceous, ?Albian) of northeast Brazil. Cretac Res 29:649-658

Martins-Neto RG (2006) Insetos fósseis como bioindicadores em depósitos sedimentares: um estudo de caso para o Cretáceo da Bacia do Araripe (Brasil). Revista Brasileira de Zoociências 8:155-183

Matos RMD (1992) The northeast Brazilian rift system. Tectonics 11:766-791

Menon F, Martill DM (2007) Taphonomy and preservation of Crato Formation arthropods. In: Martill DM, Bechly G, Loveridge RF (eds) The Crato fossil beds of Brazil: window into an ancient world. Cambridge University Press, New York, pp 79-96

Milani EJ, Davison I (1988) Basement control and transfer tectonics in the Recôncavo-Tucano-Jatobá rift. Northeast Braz Tectonophys $154: 41-70$ 
Mohr BAR, Eklund H (2003) Araripia florifera, a magnoliid angiosperm from the Lower Cretaceous Crato Formation (Brazil). Rev Palaeobot Palynol 126:279-292

Mohr KI, Brinkmann N, Friedl T (2011) Cyanobacteria. In: Reitner J, Thiel V (eds) Encyclopedia of geobiology. Springer Netherlands, Dordrecht, pp 306-311. doi:10.1007/978-1-4020-9212-1_221

Montes-Hernandez G, Sarret G, Hellmann R, Menguy N, Testemale D, Charlet L, Renard F (2011) Nanostructured calcite precipitated under hydrothermal conditions in the presence of organic and inorganic selenium. Chem Geol 290:109-120. doi:10.1016/j. chemgeo.2011.09.007

Neumann VH (1999) Estratigrafia, sedimentologia, geoquímica y diagénesis de los sistemas lacustres Aptienses-Albienses de lá Cuenca de Araripe (Nororeste do Brasil). Universitat de Barcelona, Tese de Doctorado

Neumann VH, Borregob AG, Cabrerac L, Dinod R (2003) Organic matter composition and distribution through the Aptian-Albian lacustrine sequences of the Araripe Basin, northeastern Brazil. Int J Coal Geol 54:21-40. doi:10.1016/ S0166-5162(03)00018-1

Perry RS et al (2007) Defining biominerals and organominerals: direct and indirect indicators of life. Sediment Geol 201:157179. doi:10.1016/j.sedgeo.2007.05.014

Poiré DG, López Agosti V, Albarracin VH, Arrouy MJ, Polerecky L, Farías ME (2010) Modern microbial mats from hypersaline lakes in the Puna, Andean Range, Argentina. Paper presented at the 18 international sedimentological congress, Mendoza

Ponte FC, Ponte Filho FC (1996) Estrutura geológica e evolução tectônica da Bacia do Araripe. Departamento Nacional de Produção Mineral, Recife

Porada H, Ghergut J, Bouougri EH (2008) Kinneyia-type wrinkle structures-critical review and model of formation. Palaios 23:65-77

Preiss W (1972) The systematics of South Australian Precambrian and Cambrian stromatolites. Trans R Soc Aust 96:67-100

Raff RA et al (2014) Microbial ecology and biofilms in the taphonomy of soft tissues. Palaios 29:560-569. doi:10.2110/palo.2014.043

Reeder RJ (1983) Crystal chemistry of the rhombohedral carbonates. Rev Miner Geochem 11:1-47

Reid RP, Macintyre IG, Browne KM, Steneck RS, Miller T (1995) Modern marine stromatolites in the Exuma Cays, Bahamas: uncommonly common. Facies 33:1-17. doi:10.1007/bf02537442

Reitner J (2011) Das Salz der Erde. "Leben im Extremen". Geowissenschaftliches Museum, Göttingen

Riding R (1991) Classification of microbial carbonates. In: Riding $\mathrm{R}$ (ed) Calcareous algae and stromatolites. Springer, Berlin, pp $55-87$
Riding R (2000) Microbial carbonates: the geological record of calcified bacterial-algal mats and biofilms. Sedimentology 47:179_ 214. doi:10.1046/j.1365-3091.2000.00003.x

Riding R (2008) Abiogenic, microbial and hybrid authigenic carbonate crusts: components of Precambrian stromatolites. Geol Croat 61:73-103

Rodriguez-Blanco JD, Shaw S, Benning LG (2011) The kinetics and mechanisms of amorphous calcium carbonate (ACC) crystallization to calcite, viavaterite. Nanoscale 3:265-271. doi:10.1039/ C0NR00589D

Saenger C, Miller M, Smittenberg RH, Sachs JP (2006) A physicochemical survey of inland lakes and saline ponds: Christmas Island (Kiritimati) and Washington (Teraina) Islands, Republic of Kiribati. Saline Syst 2:1-15. doi:10.1186/1746-1448-2-8

Sayão J, Kellner A (1998) Pterosaur wing with soft tissue from the Crato Member (Aptian-Albian), Santana Formation, Brazil. J Vertebr Paleontol 15:75A

Schopf JW (2006) Fossil evidence of Archaean life. Philos Trans R Soc B Biol Sci 361:869-885

Silva AL, Neumann VH (2003) Formação Crato da Bacia do Araripe: um reservatório análogo ao calcário Trairí (Formação Paracuru), Bacia do Ceará. In: $2^{\circ}$ Congresso Brasileiro de P\&D em Petróleo \& Gás, Rio de Janeiro

Sumner DY (1997) Late Archean calcite-microbe interactions; two morphologically distinct microbial communities that affected calcite nucleation differently. Palaios 12:302-318

Trichet J, Défarge C, Tribble J, Tribble G, Sansone F (2001) Christmas Island lagoonal lakes, models for the deposition of carbonate-evaporite-organic laminated sediments. Sediment Geol 140:177-189

Visscher PT, Surgeon TM, Hoeft SE, Bebout BM, Thompson Jr. J, Reid RP (2002) Microelectrode studies in modern marine stromatolites: unravelling the Earth's past? In: Taillefert M, Rozan TF (eds) Electrochemical methods for the environmental analysis of trace metal biogeochemistry. ACS symposium series, vol 220, pp 265-282. Cambridge University Press, New York

Walter MR (1972) Stromatolites and the biostratigraphy of the Australian Precambrian and Cambrian. Spec Pap Palaeontol 11:1-256

Whitton BA, Potts M (2000) Introduction to the cyanobacteria. In: Whitton BA, Potts M (eds) The ecology of cyanobacteria. Kluwer Academic, Dordrecht, pp 1-11

Wilby PR, Briggs DE, Bernier P, Gaillard C (1996) Role of microbial mats in the fossilization of soft tissues. Geology 24:787-790

Wittkop CA, Teranes JL, Dean WE, Guilderson TP (2009) A lacustrine carbonate record of Holocene seasonality and climate. Geology 37:695-698. doi:10.1130/g30056a.1 